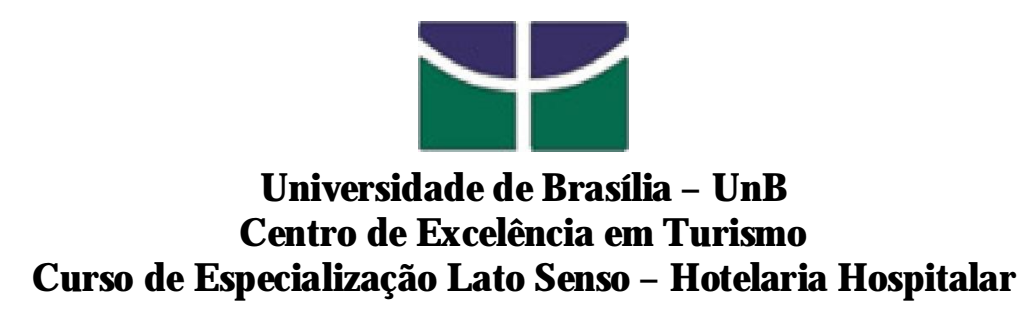

\title{
GESTÃO DE HOSPITALIDADE NA UNIDADE DE PEDIATRIA CLÍNICA DO HOSPITAL UNIVERSITÁRIO DE BRASÍLIA
}

\author{
Autora: Tereza Garcia Braga
}

Orientadora: Prof ${ }^{a}$. Doutora Iara Lúcia Gomes Brasileiro

Brasília - 2009 


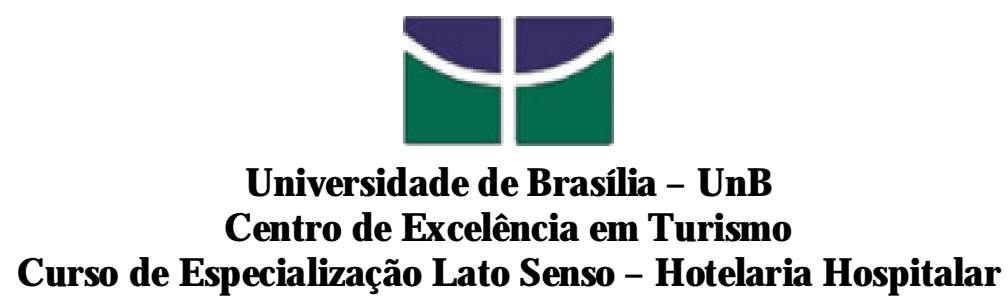

Universidade de Brasília - UnB

centro de Excelência em Turismo

Curso de Especialização L ato Senso - H otelaria Hospitalar

\title{
GESTÃO DE HOSPITALIDADE NA UNIDADE DE PEDIATRIA CLÍNICA DO HOSPITAL UNIVERSITÁRIO DE BRASÍLIA
}

\author{
Autora: Tereza Garcia Braga \\ Orientadora: Prof ${ }^{a}$. Doutora Iara Lúcia Gomes Brasileiro
}

Monografia apresentada ao Centro de Excelência em Turismo - CET, da Universidade de Brasília UnB, como requisito parcial à obtenção do grau de Especialista em Hotelaria Hospitalar. 
Aos meus pais, Domingos e Genoveva, e à avó 'Mãe Dindinha', pelos exemplos de vida. Onde estiverem, esta conquista também é de vocês. 


\section{AGRADECIMENTOS}

Ao Centro de Excelência em Turismo da Universidade de Brasília, por ter oportunizado a realização do Curso de Especialização em Hotelaria Hospitalar.

À minha orientadora, Prof ${ }^{a}$. Dr ${ }^{a}$. Iara Lúcia Gomes Brasileiro pela dedicação e ensinamentos.

A todos os professores do curso que, com seus conhecimentos, contribuíram para aumentar o meu.

Aos funcionários da secretaria do curso. pela dedicação e respeito.

À Unidade de Pediatria Clínica do Hospital Universitário de Brasília, pela oportunidade de realização deste trabalho.

À Rosilane, amiga, companheira e coorientadora, pelo apoio extremo e decisivo.

Aos acompanhantes dos menores hospitalizados na Unidade de Pediatria Clínica, por terem compreendido a importância desta pesquisa e pela colaboração com a mesma.

Aos amigos Manuela, Geniel e Glaudistonia, pelo apoio solidário.

Aos colegas de serviço e alunas do curso de enfermagem em estágio na Unidade, pela colaboração.

Aos meus colegas de curso, pela convivência durante todo o período do curso.

A todos que, direta ou indiretamente, contribuíram para a realização deste trabalho.

Ao meu Deus, sempre presente em todos os momentos, principalmente nos mais difíceis. 
"A prender é descobrir aquilo que vocêjá sabe.Fazer é demonstrar aquilo que vocêjá sabe.Ensinar é lembrar aos outros que eles sabem tanto quanto você.Somos todos aprendizes, fazedores, professores."

Richard B each 


\section{LISTA DE ILUSTRAÇÕES}

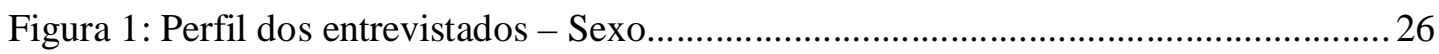

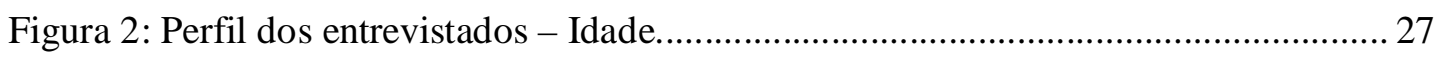

Figura 3: Perfil dos entrevistados - Grau Instrução...................................................... 27

Figura 4: Perfil dos entrevistados - Procedência........................................................ 28

Figura 5: Perfil dos entrevistados - Renda Familiar..................................................... 29

Figura 6: Perfil dos entrevistados - Número de Pessoas que Trabalha na Família............. 29

Figura 7: Perfil dos entrevistados - Número de Pessoas na Família................................... 30

Figura 8: Perfil dos entrevistados - Tempo de Hospitalização........................................... 31

Figura 9: Perfil dos entrevistados - Número de Hospitalizações..................................... 31

Figura 10: Qualidades dos Serviços e Instalações - Desempenho da Equipe Médica e de

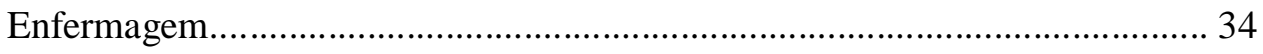

Figura 11: Desempenho da Equipe de Pedagogia e Recreação..............................................35

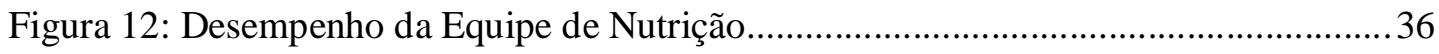

Figura 13: Qualidade da Relação com os Profissionais.................................................... 39

Figura 14: Qualidade dos Equipamentos/aparelhos e Alimentação Oferecidos pela Unidade

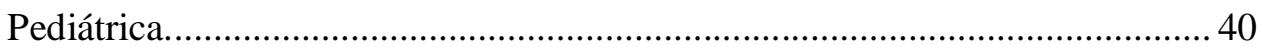

Figura 15: Qualidade das Instalações da Unidade Pediátrica.......................................... 41

Figura 16: Qualidade do Atendimento ao Acompanhante............................................... 42 


\section{LISTA DE QUADROS}

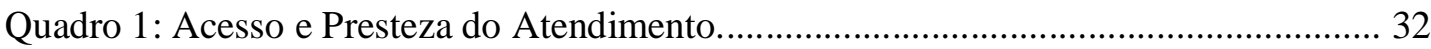

Quadro 2: Instalações, Equipamentos Auxiliares nos Cuidados e Tratamento dos

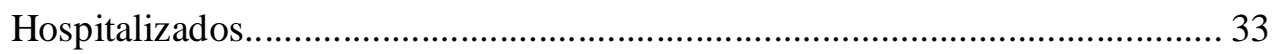

Quadro 3: Acesso e Presteza dos Serviços.................................................................... 37

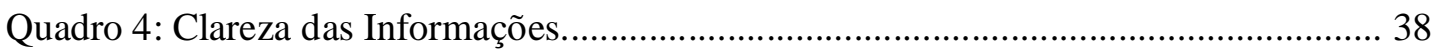




\section{RESUM 0}

A hospitalidade tem uma definição ampla, que abrange não somente o setor comercial, mas também as relações entre as pessoas por meio de trocas no âmbito econômico, social e psicológico. Desta forma, a hospitalidade hospitalar é o ato de receber, acolher, hospedar, alimentar e entreter aqueles que buscam auxílio em unidades de saúde, ao favorecer a construção de confiança entre os clientes e os profissionais. Assim, este trabalho teve como objetivo geral analisar o atendimento oferecido na Unidade de Pediatria Clínica - UPC do Hospital Universitário de Brasília - HUB e como objetivos específicos: caracterizar a arquitetura; avaliar as atividades e espaços lúdicos e pedagógicos; avaliar as condições do serviço de nutrição e dietética e estabelecer comparação das condições atuais de hospitalidade da UPC/HUB, por meio de um Estudo de Caso realizado com 40 acompanhantes, que teve duas fontes de procedimentos: documental e entrevista estruturada, com aplicação de questionários, nos quais ficou demonstrada a possibilidade de afirmação e de confronto de respostas, por meio do cruzamento dos dados obtidos com o referencial teórico e da análise dos dados. Pode-se concluir que a UPC/HUB possui hospitalidade em grau considerado bom em aspectos como gentileza, atendimento das equipes de saúde, atenção e acesso ao serviço. Como itens negativos foram citados as instalações, com espaços inadequados, quartos e

banheiros desconfortáveis, móveis velhos e higienização precária. Acredita-se que a adequação desses pontos é possível e tornaria melhor a hospitalidade do ambiente estudado dentro do conceito da hotelaria hospitalar.

Palavras-chave: Hospitalidade. Hotelaria hospitalar - Gestão. Pediatria. 


\begin{abstract}
Hospitality has a broad definition which includes not only business activities, but all human relations which involve economic, social and psychological exchanges. Thus, hospital hospitality is the human act of welcoming people, providing accommodation, food and entertainment for all those that seek healthcare, as it increases the level of confidence between patients and health professionals. The main purpose of this study was to analyze the service provided in the Pediatric Unit at the University Hospital of Brasilia (HUB) and as specific objectives: to describe and analyze the unit's setting, areas for play/school activities, nutrition and dietary service, in terms of its hospitality service. A case study was carried out using documental analysis and structured interviews with a sample of 40 family caregivers. A pretested questionnaire was applied and data analysis was conducted by cross reference with the chosen theoretical framework. The study concluded that the Pediatric Unit at HUB offers a good level of hospitality in terms of kindness, service provided by the staff, attention and access to the unit. As negative conditions, the participants cited inadequate space and physical structure, uncomfortable rooms and lavatory facilities, worn furniture and precarious cleaning service. With adequate adaptations it is possible to improve the hospitality of this setting according to the concept of hospital hospitality.
\end{abstract}

Key words: Hospitality. Hospital hospitality - Management. Pediatrics. 


\section{SUMÁRIO}

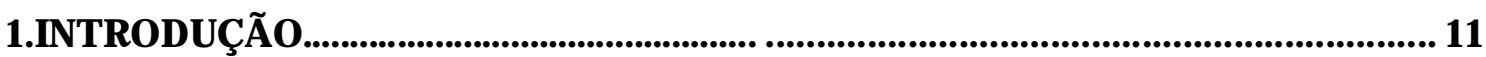

2.FUNDAMENTAÇÃO TEÓRICA

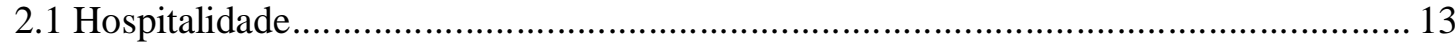

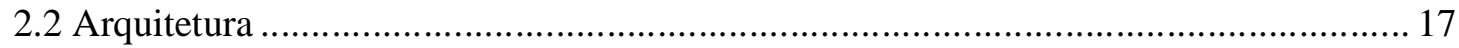

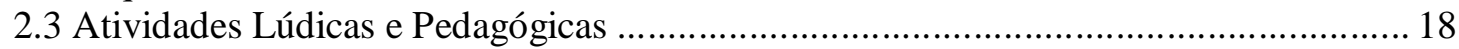

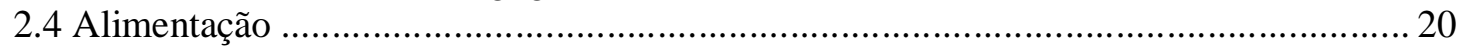

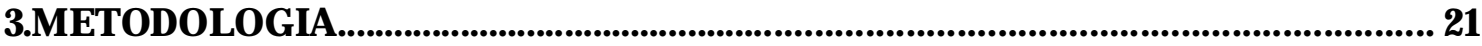

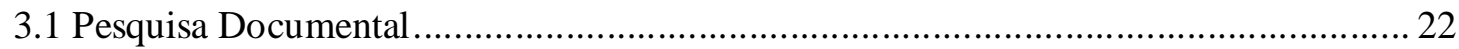

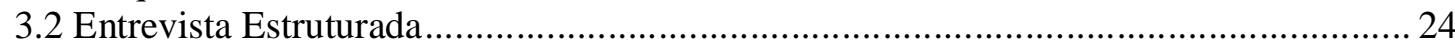

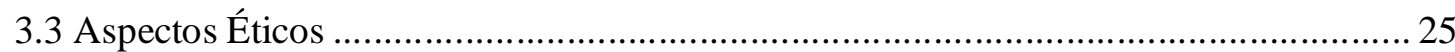

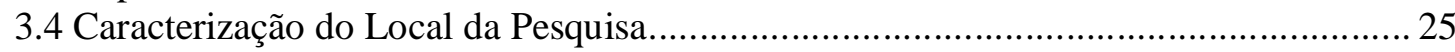

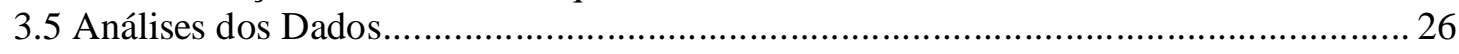

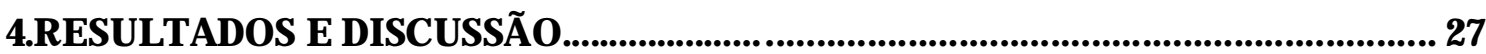

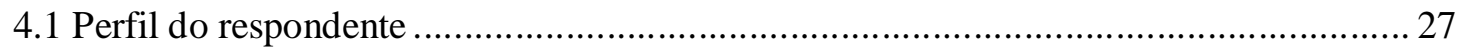

4.2 Qualidades dos Serviços e Instalações .......................................................................... 33

4.3 Itens mais importantes ................................................................................... 37

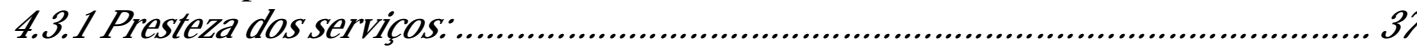

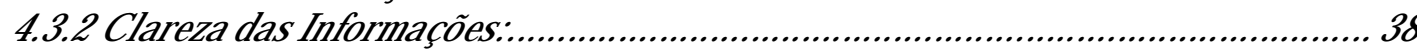

4.3.3 Qualidade da relação com os profissionais: .................................................. 39

4.3.4 Q ualidades dos Equipamentos: .............................................................. 40

4.3.5 Qualidades das instalações ......................................................................... 41

4.3.6 Q ualidades de atendimento ao a companhante: .............................................. 42

4.4 Informações complementares................................................................................ 43

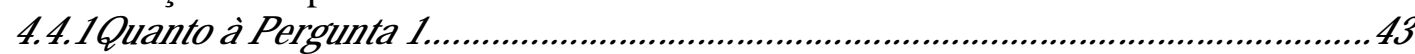

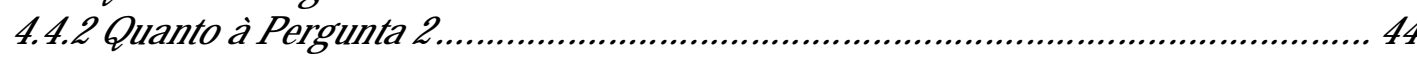

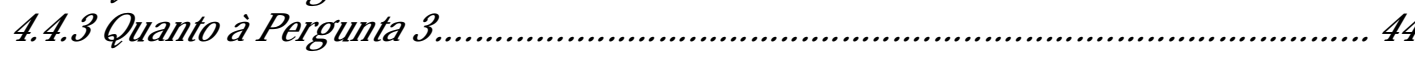

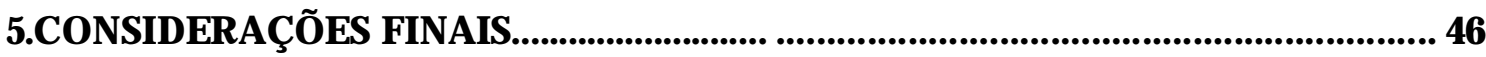

REFERÊNCIAS

APÊNDICES

ANEXOS 


\section{INTRODUÇÃO}

A valorização da hospitalidade nas unidades hospitalares se torna mais evidente a cada dia, sendo as Unidades Pediátricas lugares onde a presença de familiares é obrigatória de acordo com a Lei n.8069/90 que reconhece como direito fundamental do menor, enquanto cidadão a permanência do acompanhante durante todo período de sua hospitalização

(CRISTO 1999). Diante desse quadro, é que está fundamentado o desejo de estudar e compreender a hospitalidade na Unidade de Pediatria Clínica do Hospital Universitário de Brasília (UPC/HUB) e teve como pilares três variáveis: arquitetura, alimentação e atividade lúdica e pedagógica.

Para Camargo (2004) a hospitalidade é um ato humano exercido no contexto doméstico, público e profissional de recepcionar, hospedar, alimentar e entreter pessoas temporariamente deslocadas de seu ambiente natural. Essa definição é corroborada por Dytz (1998), ao afirmar que um ambiente seguro, limpo e dieta saudável são alguns dos fatores favoráveis para o bem estar e, quando aplicado à criança os benefícios são maiores. Este aconchego e conforto estão relacionados com a hospitalidade.

Boeger (2005) relata que a área pediátrica deve possuir cardápio balanceado e nutritivo, porém, voltado para o desejo usual de crianças. A hospitalidade não se restringe só em leito e alimentação. Para Dencker (2003) implica também em entretenimento de alguma forma e por algum tempo.

Verbiste (2006) acrescenta que a necessidade desse diferencial não é privilegio só das organizações da indústria da hospitalidade de alimentação e de hospedagem. Como diferencial de negócios, deve estar presente nas empresas, inclusive em hospitais que tem como seu maior capital o ser humano. 
A partir dessas considerações, optou-se por um estudo que utilizou pesquisa documental e entrevista estruturada, acrescido de estudo exploratório bibliográfico dos temas pertinentes ao estudo, para estabelecer um elo entre o referencial teórico atual e a realidade do serviço pesquisado.

A justificativa para desenvolver este estudo está diretamente ligada ao fato de a hospitalidade estar inserida em todas as instituições que hospedam, sendo a UPC/HUB parte de uma instituição que recebe, hospeda e acolhe pessoas em busca de auxílio à saúde. Daí surge a necessidade de oferecer à criança e ao adolescente hospitalizado, o direito à continuidade do seu desenvolvimento e também do seu processo de escolaridade. Esse contexto foi o despertar para a realização desta pesquisa sobre a hospitalidade oferecida na UPC/HUB.

Mesmo diante de todas as alterações emocionais ocasionadas pela hospitalização a criança continua se desenvolvendo, experimentando e aprendendo. Para tanto, é necessário que se compreenda que a unidade acolhe pessoas com direitos que merecem do serviço melhores acomodações, alimentação, lazer, tratamento de saúde adequado e eficaz por parte de todos os profissionais que ali desempenham suas funções. Dai se estabeleceu o objetivo geral: Analisar a hospitalidade na Unidade de Pediatria Clínica do Hospital Universitário de Brasília UPC/HUB. Como objetivos específicos: caracterizar a arquitetura; avaliar as atividades e espaços lúdicos e pedagógicos; avaliar as condições do serviço de nutrição e dietética da UPC/HUB e estabelecer comparação das condições atuais de hospitalidade da UPC/HUB com os conceitos vigentes. Deste modo se poderá ter parâmetros para a construção de paradigmas que proporcionem um acolhimento como preconiza o conceito de hospitalidade. 


\section{FUNDAMENTAÇÃO TEÓRICA}

\subsection{Hospitalidade}

Dentro do referencial teórico é importante rever a origem etimológica da hospitalidade: hospitalitas, palavra latina derivada de hospitalis, que "designava a hospedagem gratuita e a atitude caridosa oferecida aos indigentes e aos viajantes acolhidos nos conventos, hospícios e hospitais" (GRINOVER, 2002).

Para Watanabe (2008) essa hospitalidade sofreu alteração ao longo dos tempos nas suas características e finalidades distintas, como recepção e tratamento dos doentes mediante, inclusive, formação voltada para uma prática mais hospitaleira, oferecendo algo que lembre o ambiente familiar. Essa alteração segundo Grinover (2002) foi estabelecida pelos fatores como a industrialização, explosão demográfica, desenvolvimento científico e tecnológico dentre outros que mudaram essa relação entre hóspedes e anfitriões. Ocasiona-se assim uma relação transformadora que proporciona uma enorme riqueza de conhecimentos.

Para Campos (2005), a hospitalidade está presente na história da humanidade como forma de abrigar, bem receber, negociar, fazer política, estimular as artes e ajudar no crescimento das comunidades, e sempre significou a busca de segurança, alimento e conforto. Esta afirmação vem comprovar que a hospitalidade é algo que se abre ou está aberto previamente para alguém que não é esperado nem convidado, para quem quer que chegue como um visitante absolutamente estranho (DERRIDA, 2003 apud PEREZ, 2007).

Camargo (2004) destaca que a relação humana é uma dádiva que parte de alguém, o que implica em retribuir com uma nova dádiva. Acrescenta que é um ritual básico do vínculo humano. É um processo de comunicação interpessoal repleto de conteúdos verbais e não verbais e que estabelece fórmulas rituais que variam de grupo social para grupo social, porém, com o mesmo significado, desejo ou recusa de vínculo humano. 
Esse mesmo autor ainda caracteriza a hospitalidade exercida no contexto doméstico, público e profissional de recepcionar, hospedar, alimentar e entreter pessoas temporariamente deslocadas de seu ambiente natural, da seguinte maneira.

\section{Os Tempos/Espaços da Hospitalidade Humana}

\begin{tabular}{|c|c|c|c|c|}
\hline & Recepcionar & Hospedar & Alimentar & Entreter \\
\hline Doméstica & $\begin{array}{l}\text { Receber pessoas } \\
\text { em casa, de } \\
\text { forma } \\
\text { intencional ou } \\
\text { causal. }\end{array}$ & $\begin{array}{l}\text { Fornecer pouso e } \\
\text { abrigo em casa } \\
\text { para pessoas. }\end{array}$ & $\begin{array}{l}\text { Receber em casa } \\
\text { para refeições e } \\
\text { banquetes. }\end{array}$ & $\begin{array}{l}\text { Receber para } \\
\text { recepções e } \\
\text { festas. }\end{array}$ \\
\hline Pública & $\begin{array}{l}\text { A recepção em } \\
\text { espaços e órgãos } \\
\text { públicos de livre } \\
\text { acesso. }\end{array}$ & $\begin{array}{l}\text { A hospedagem } \\
\text { proporcionada } \\
\text { pela cidade e pelo } \\
\text { país, incluindo } \\
\text { hospitais, casa de } \\
\text { saúde, presídios... }\end{array}$ & $\begin{array}{l}\text { A gastronomia } \\
\text { local. }\end{array}$ & $\begin{array}{l}\text { Espaços } \\
\text { públicos de } \\
\text { lazer e eventos. }\end{array}$ \\
\hline Comercial & $\begin{array}{l}\text { Os serviços } \\
\text { profissionais de } \\
\text { recepção }\end{array}$ & Hotéis & A restauração & $\begin{array}{l}\text { Eventos e } \\
\text { espetáculos. } \\
\text { Espaços } \\
\text { privados e lazer }\end{array}$ \\
\hline Virtual & $\begin{array}{l}\text { Folhetos, } \\
\text { cartazes, internet, } \\
\text { telefone e email }\end{array}$ & $\begin{array}{l}\text { Sites e } \\
\text { hospedeiros de } \\
\text { sites }\end{array}$ & $\begin{array}{l}\text { Programa na } \\
\text { mídia e sites de } \\
\text { gastronomia. }\end{array}$ & $\begin{array}{l}\text { Jogos e } \\
\text { entretenimento } \\
\text { na mídia }\end{array}$ \\
\hline
\end{tabular}

Fonte: Camargo, 2004, p. 84.

Para efeito didático Camargo (2004) ainda considera como leis da hospitalidade

os itens a seguir:

- A hospitalidade começa com uma dádiva. - Nem toda dádiva está inserida na hospitalidade, mas toda ação de hospitalidade começa com uma dádiva precedida de um convite ou de um pedido de ajuda.

- A dádiva implica sacrifício. - Agradar o hospede significa abrir mão de algo que se tem a favor dele.

- Toda dádiva traz implícito algum interesse. - Esse interesse pode ser nobre, como o que ocorre na ajuda ao próximo em necessidade, mas mesmo nesse caso, essa ação de dar é de plena ambigüidade.

- O dom deve ser recebido, aceito. - Recusar a dádiva desencadeia o mecanismo oposto da hospitalidade, ou seja, hostilidade.

- Receber implica aceitar uma situação de inferioridade diante do doador. Quem recebe a dádiva deve manifestar alegria mesmo sentindo que assume um débito para com aquele que doa. 
- Quem recebe deve retribuir. - Significa reestruturar o dom, criar uma nova dádiva.

A hospitalidade é um processo de comunicação interpessoal. Carregado de contatos verbais e não verbais que constituem, rituais que variam de grupo social para grupo social.

Para Boeger (2005), o conceito de hospitalidade unido com a indústria da mesma nos tempos atuais, transmite a idéia de grandeza desses serviços, não só nos requisitados hotéis, restaurantes, como também em clubes, cruzeiros, universidades e escolas; e porque não em hospitais? Acrescenta ainda, que é o ato de receber com bom acolhimento, o qual está bem definido na Política Nacional de Humanização (PNH) que ressalta o acolhimento como facilitador na construção de confiança entre os clientes de saúde e os profissionais além, de contribuir para promover a cultura de solidariedade (BRASIL, 2008).

Este conceito é reafirmado por Verbiste (2006), ao enfatizar que a hospitalidade tanto nos hotéis como nos hospitais configura-se como aspecto ímpar na constituição destes dois ambientes e deve estar presente nas relações de troca de experiências e prestação de serviço nestas organizações mesmo com significativas diferenças entre seu público e sua missão.

Assim sendo, o ato de acolher, receber e hospedar aqueles que chegam em busca de auxílio ocorre quando é proporcionado a eles um atendimento eficaz e eficiente, promove o bem-estar e boas qualidades nas relações de trocas entre o anfitrião e o hóspede. Essas relações humanas, em qualquer atendimento à saúde, devem agregar à eficiência técnica e cientifica uma postura ética que respeite a singularidade das necessidades do usuário e do profissional, que acolha o desconhecido e imprevisível e aceite os limites de cada situação. Trata se de um ser e fazer que se inspire numa disposição de abertura e respeito ao outro como um ser autônomo e digno (BRASIL. 2001).

Essa relação fica evidente quando Levinas (1988 apud PEREZ, 2007) afirma que é o outro que devo servir sem perguntar pelo nome, porque é o outro que me constitui como tal, 
eu sou responsável por ele porque ele me constitui. Mesmo sem saber quem é o outro, existe uma responsabilidade ética.

Vale lembrar ainda que, segundo Verbiste (2006), até meados do século XVIII, a formação médica não incluía a experiência hospitalar e por sua vez os hospitais até 1780 eram conhecidos como locais de assistência aos pobres, pois, antes mesmo da cura propriamente dita, cuidar dos pobres e enfermos era uma forma de salvação espiritual e era missão dos hospitais. Esta atitude já caracterizava a hospitalidade hospitalar, e era praticada pela presença permanente das religiosas nas Santas Casas de Misericórdia, o que justifica a relação entre a igreja e os hospitais por terem como responsabilidade acolher pessoas marginalizadas pela sociedade, representadas nas figuras dos doentes, do pobre, do órfão e do peregrino.

Genehr (2008) destaca que o cristianismo não praticou a hospitalidade no fato referido à peregrinação de Maria e José, visto que ninguém os acolheu para o nascimento de Jesus, porém, as cruzadas sim, iniciadas no século XI, com o propósito de conquistar a Terra Santa. As ordens religiosas recebiam enfermos, feridos e peregrinos.

Esta característica é própria da origem da palavra hospital derivada do termo hospitalidade. Por essa razão estabelecer ações acolhedoras nas relações humanas em qualquer atendimento de saúde é imprescindível para se concretizar a hospitalidade hospitalar, pois, ela transcende o ato de hospedar, alimentar e entretenimento. É uma relação de troca entre pessoas. Para Camargo (2004), a hospitalidade é um campo ilimitado, que pode ser estudado sob o ponto de vista de diversas áreas. 


\subsection{Arquitetura}

Segundo Boeger (2005), a arquitetura hospitalar estabelece um papel fundamental no que se refere ao conforto dos clientes de saúde e do espaço para os trabalhadores da saúde. Os pacientes são hóspedes enfermos, portanto, requerem atenção especial que concilie a saúde com a hospedagem e torne o ambiente mais acolhedor para eles e suas famílias.

Para Quevedo (2006), alguns fatores devem ser considerados na execução do projeto arquitetônico como o terreno, o entorno, a insolação, a acústica, a facilidade de acesso, a movimentação entre outros. Refere-se ainda, à importância de busca de informações sobre as necessidades estruturais e tecnológicas que se obtêm por meio do conhecimento de dirigentes, médicos, enfermeiros, nutricionistas dentre outros profissionais envolvidos. Influencia, também, diretamente sobre a utilização de fluxos corretos de entrada e saída de material infectante (roupas, lixos, equipamentos entre outros), conforme afirma BOEGER (2005).

Diante do referenciado acima, o dimensionamento, a localização e o uso de espaço físico de qualquer hospital são de extrema importância, pois estão intimamente relacionados com a segurança e o conforto e, consequentemente com a humanização do atendimento ao cliente de saúde. Assim sendo, Quevedo (2006) relaciona pontos a serem considerados tais como:

- Possibilidade de expansão para atender às previsões do plano diretor (que estabelece diretrizes para o desenvolvimento da instituição);

- Organização de atividades por setor, dando funcionalidade ao conjunto;

- Flexibilidade na adaptação de diferentes e novos usos e tecnologia;

- Proporcionalidade entre serviços e número de leitos;

- Humanização dos espaços;

- Racionalização de trabalhos e processos;

- Planejamento para o futuro. 
A flexibilidade da planta física além de oferecer garantia de biossegurança relativa à infecção hospitalar oferece também prevenção de acidentes biológicos. É dever do administrador hospitalar oferecer o melhor atendimento possível, considerando o ambiente físico e emocional. Portanto, deve criar ambientes que ofereçam espaços físicos que visem ao conforto focado na privacidade e individualidade dos clientes de saúde; possibilitam o respeito aos valores culturais, autonomia e vida coletiva, além de contribuir para a promoção do bem-estar, desfazendo com isso o mito de que as unidades de saúde são frias e hostis. (BRASIL, 2008).

\subsection{Atividades Lúdicas e Pedagógicas}

Ao se falar de atividades lúdicas e pedagógicas, vale enfatizar o lazer que, segundo Quevedo (2006), é importante e um direito de todo ser humano. Tratando-se de clientes de hospitais não poderia ser diferente, pois estes se encontram fragilizados, com saúde debilitada e, portanto, necessitados de atividades lúdicas compatíveis com seu estado e que lhes proporcionem bem estar.

Nas UPC a brinquedoteca tem como objetivo geral auxiliar as crianças e adolescentes e respectivas famílias, enfrentar de forma mais amena a hospitalização, recuperando a autoconfiança e resgatando a capacidade criativa, além de intensificar as trocas afetivas entre familiares. Proporciona um espaço no qual a criança passa a brincar livremente, eliminando aquilo que está bloqueando a liberação de potencialidade ou o impedimento ao acesso à felicidade (BOEGER, 2005).

Considerando os efeitos emocionais negativos decorrentes da hospitalização tais como: a quebra da rotina diária, interrupção de desenvolvimento nas crianças e adolescentes, agravos e desequilíbrio também em seus familiares. Boeger (2005) afirma ainda que a brinquedoteca hospitalar oferece à criança internada um espaço que pode amenizar o sofrimento causado pela estadia hospitalar. Isso ocorre por meio de atividade lúdica, cultural, 
auxiliando-os a restabelecer o contato com o mundo externo. Readquirem, assim, a autoconfiança e melhora a colaboração nos procedimentos médicos. Contudo, é importante salientar que todos os brinquedos devem ser laváveis e autorizados pelo controle de infecção hospitalar.

Algumas crianças internadas não se desenvolvem academicamente nesse período pelo fato de terem eliminado toda chance de socialização com outras crianças, por tirarem delas o conforto de casa, seus brinquedos e suas rotinas. O autor enfatiza ainda a Declaração dos Direitos da Criança das Nações Unidas, afirmada no Artigo 7:

\footnotetext{
A criança deve ter todas as possibilidades de se entregar a jogos e atividades recreativas, que devem ser orientadas para os fins visados para a Educação; a sociedade e os poderes públicos devem esforçar-se para favorecerem o exercício deste direito reconhecido no artigo $31^{\circ}$ da Constituição, sobre os direitos humanos. (BOEGER, 2005, p.40).
}

A brinquedoteca hospitalar é um espaço onde a criança pode preservar o lado saudável, resgatar seu potencial e o direito à infância. Adriana Arantes, pedagoga da UPC/HUB, afirma em entrevista que a brinquedoteca da unidade pesquisada neste trabalho está organizada com o intuito de ser um espaço convidativo para brincar, interagir, manipular, criar, ler, em resumo, para o desenvolvimento social. Acrescenta ainda que estão em construção dois projetos: Classe Hospitalar (compreende o acompanhamento escolar de crianças e adolescentes hospitalizados, com a finalidade de minimizar a defasagem escolar) e Estimulação Precoce (estimular o desenvolvimento cognitivo das crianças internadas por meio de interações lúdicas com músicas, brincadeiras, entre outras), pois acredita que essas atividades contribuem para a socialização humanizada. 


\subsection{Alimentação}

A hospitalidade passa necessariamente pelo estudo das condutas alimentares, contextualizadas pelas crenças, pelos valores e pelas estruturas locais das diferentes sociedades. $\mathrm{O}$ ato de repartir a comida, bebida e espaço ganharam novas dimensões diferentes daquelas de tempos remotos onde o desconhecimento de conservação obrigava a dividir a caça para ser consumida em tempo hábil (GENEHR, 2008).

Para tanto, é necessário não deixar de lado o contexto higiênico e a qualidade alimentar. Ainda que este alimento seja simbólico, sob a forma de um copo de água ou pão que se reparte como em algumas culturas (CAMARGO, 2004).

Em se tratando de gastronomia hospitalar, Boeger (2005) afirma que ela surge com o objetivo de confrontar a adequação da dieta à patologia do cliente de saúde, levando em consideração as aversões alimentares e seus hábitos regionais, sem esquecer o principal objetivo, o restabelecimento do seu estado nutricional. $\mathrm{O}$ autor acrescenta, ainda, que o principal objetivo do Setor de Nutrição e Dietética na unidade hospitalar é o restabelecimento do estado nutricional do paciente por meio de dietas variadas, tais como livre (sem restrição), líquida, pastosa, dentre outras. Por outro lado, tem se esquecido do glamour da gastronomia e por essa razão, a comida hospitalar ganhou fama de comida sem tempero, cor e criatividade.

Para o autor, outro ponto importante é diferenciar o atendimento na área pediátrica. A experiência mostra que o cardápio deve ser voltado aos desejos usuais das crianças, mesmo que seja uma dieta balanceada. Uso de cores nos alimentos e utensílios provoca encantamento a esses clientes.

Teichmann (2000) afirma que o profissional que prescreve a alimentação de pessoas sadias ou enfermas deve ter sempre em mente que o fator emocional favorece a aceitação ou não do cardápio. Conceitua o alimento como toda substância que fornece ao ser humano os elementos necessários à manutenção de sua forma e ao desenvolvimento de suas atividades. 
A mesma autora ressalta ainda que é necessário considerar os seguintes aspectos:

- Cor - os alimentos coloridos despertam os desejos de consumo;

- Formas - apresentações merecem cuidados;

- Sabores - é de extrema importância no preparo dos alimentos;

- Textura - a variedade dá maior encantamento ao cardápio;

- Temperos - caracterizam o sabor próprio dos pratos

- Ingredientes - fazem parte da criatividade de quem os prepara pela diversificação de sabores semelhantes;

- Tipo de preparo - enriquece a refeição na aparência e na degustação;

- Temperatura - os alimentos devem ser servidos em temperatura adequada ao tipo de prato;

- Viabilidade - a aquisição de insumos pode limitar o cardápio quando se leva em conta a qualidade, mão de obra e equipamentos;

- Conhecimentos de preparações básicas e nomenclatura clássica - condição indispensável para que o responsável pela elaboração do cardápio possa avaliar o aspecto, o sabor, a textura, os ingredientes, entre outros.

3. METODOLOGIA

Para responder aos objetivos estabelecidos, foi realizado um Estudo de Caso com uma abordagem qualitativa. Para o propósito traçado, a abordagem qualitativa é pertinente, por ser este um enfoque metodológico que permite analisar o conjunto de expressões humanas constantes nas estruturas, nos processos, nos sujeitos e nas representações e abre um amplo espectro para a interpretação dos conteúdos expressos (MINAYO, 2008).

Entre as várias formas que pode assumir uma pesquisa qualitativa, destaca-se o Estudo de Caso, pois, pode ser bem delimitado, com contornos claramente definidos no desenrolar do estudo. Segundo Lüdke e Marli (1986), o Estudo de Caso se constitui numa unidade dentro de um sistema mais amplo. 
Becker (1999) aponta que um Estudo de Caso tem um propósito duplo, porque tenta chegar a uma compreensão abrangente do grupo, e ao mesmo tempo tenta desenvolver declarações teóricas mais gerais, sobre regularidades do processo e estruturas sociais.

\begin{abstract}
Um estudo de caso pode ser realizado voltado para um individuo uma organização ou uma comunidade, nas ciências sociais. É utilizado para adquirir conhecimento do fenômeno adequadamente a partir da exploração intensa de um único caso (BECKER, 1999, p. 117).
\end{abstract}

A coleta de dados abrangeu dois procedimentos, a saber: pesquisa documental e entrevista estruturada, técnicas capazes de fornecer informações antecipadas e resultados uniformes.

\title{
3.1 Pesquisa Documental
}

A pesquisa documental é uma das técnicas realizadas com o intuito de recolher informações prévias sobre o campo de interesse (MARCONI; LAKATOS, 2002). Nessa pesquisa a fonte de coleta de dados está restrita a documentos, onde podem ser utilizadas três variáveis: 1) fontes escritas ou não; 2) fontes primárias ou secundárias; 3) fontes contemporâneas ou retrospectivas, dependendo do objetivo da pesquisa. Como exemplo, têmse a planta baixa da Unidade pesquisada (Anexo A).

O estudo mostrou um déficit de registros escritos no HUB, supõe-se que a memória escrita esteja comprometida por uma série de razões, tais como: troca de missão do hospital de acordo com o que se segue. Construído pelo extinto Instituto de Pensão e Aposentadoria dos serviços do Estado (IPASE), a partir de estrutura inacabada pertencente à Fundação Hospitalar do Distrito Federal, denominou-se, inicialmente, Hospital dos Servidores da União (HSU).

O então Presidente da Republica, General Emilio Garrastazu Médici inaugurou em 1972 com o seu nome, Hospital do Distrito Federal Presidente Médici (HDFPM). Em 1976, com a extinção do IPASE, o HDFPM passou a ser administrado pelo Instituto de Assistência Médica da Previdência Social (INAMPS). Em 1987, com a implantação do 
Sistema Unificado e Descentralizado de Saúde (SUDS), foi integrado à rede de serviços do DF por meio de convênio assinado pela Universidade de Brasília (UnB). Com a criação dos Ministérios da Saúde, Educação, dentre outros, passou a se chamar Hospital Docente Assistencial (HDA), reconhecido como $38^{\circ}$ Hospital Universitário Brasileiro.

Em 1990, o hospital foi cedido pelo INAMPS a UnB, passando a denominar-se HUB (CARDOSO et al, mimeo).

Documentos como a planta baixa da Unidade estudada (Anexo A) favorece a caracterização do espaço físico construído para as crianças e não para os acompanhantes, pois, na época de sua construção, não existia a obrigatoriedade da presença constante do acompanhante. O manual de normas e rotinas que orienta o trabalho da enfermagem e serviu como base para a elaboração de uma cartilha educativa (Anexo B), para os acompanhantes indígenas dos menores hospitalizados, de modo a facilitar o processo de humanização solidária na UPC/HUB.

Para melhor caracterizar a hotelaria hospitalar no HUB, fez-se uma entrevista com a chefe da Divisão Administrativa do HUB, Hezira S. van der Broocke de Castro, em 05/08/09. Obteve-se a confirmação da não existência de documento que normatize o serviço de Hotelaria Hospitalar; todavia, a gestora informou que em agosto de 2002 foi criada a Divisão de Hotelaria - DH que abrangia os serviços de internações e altas, lavanderia, rouparia, governança e higienização.

Em 2008, a DH passou a integrar a Divisão Administrativa - DAD. Hoje os elementos de hotelaria presentes estão retratados pelos serviços de lavanderia e rouparia. A implantação de outros elementos depara-se com dificuldades de recursos administrativos e econômicos segundo a chefe da DAD. 


\subsection{Entrevista Estruturada}

Segundo Bauer e Gaskell (2004), a entrevista estruturada é realizada por meio de uma série de questões predeterminadas, ou seja, segue um roteiro previamente estabelecido em formulário elaborado e efetuado de preferência com pessoas selecionadas de acordo com o objeto de pesquisa.

Nesta técnica, a padronização faz-se necessária, uma vez que se buscam resultados uniformes entre os entrevistados, além de permitir resultados estatísticos e comparação imediata. Neste estudo foi realizado um termo de consentimento (Apêndice I) assinado pelos respondentes e um questionário fechado (Apêndice II), com base no documento elaborado pelo Comitê Técnico do Programa Nacional de Humanização (CTPNH), cedido pela Secretaria de Estado de Saúde do Distrito Federal (SES/DF). Com esse questionário entrevistou-se quarenta (40) acompanhantes das crianças e adolescentes hospitalizados na UPC/HUB no período 13 de julho a10 de agosto de 2009.

O questionário (Apêndice II) utilizado foi composto por dezoito perguntas fechadas e três abertas. Os dados obtidos foram analisados e agrupados em 5 partes distintas: a primeira refere-se ao perfil dos entrevistados tais como sexo, idade, grau de instrução, procedência, número de pessoas na família, número de pessoas que trabalham na família, renda familiar, tempo de hospitalização e número de hospitalização. A segunda parte trata da qualidade dos serviços e instalações, onde se inclui: facilidade, presteza e rapidez no atendimento, aparência da UPC/HUB, conforto, quantidade e qualidade de roupas de cama e banho, nível de silêncio, qualidade das refeições, acesso ao telefone, espaço para atividade de convivência e mobiliário. Na terceira parte destaca-se: atendimento prestado pela equipe médica e de enfermagem; pedagogia e recreação; nutrição; identificação clara; gentileza; interesse e atenção; compreensão das necessidades; privacidade no atendimento; informações 
claras e compreensíveis sobre diagnóstico, tratamento, atividades pedagógicas e alimentação oferecidas. Na quarta parte, buscou-se saber quais itens mais importantes na visão dos entrevistados (avaliação da prioridade dos mesmos). Na quinta parte do questionário levantou-se informações complementares que possibilitassem deixar os respondentes à vontade para completarem as avaliações com algo que não estava contemplado nas perguntas fechadas.

\subsection{Aspectos Éticos}

O presente estudo foi submetido à apreciação da Divisão de Pesquisa do HUB, a Diretoria Adjunta de Ensino e Pesquisa (DAEP), em seguida ao Comitê de Ética, em Pesquisa da Faculdade de Medicina da UnB. Foi aprovado sob o registro 045/09 (Anexo C). O estudo foi estruturado com base na Resolução do Conselho Nacional de Saúde (CNS) 196/1996, intitulada Diretrizes e Normas Regulamentadoras de Pesquisas Envolvendo Seres Humanos (BRASIL, 1997).

\subsection{Caracterização do Local da Pesquisa}

A UPC/HUB tem como objetivo prestar assistências à crianças e adolescentes hospitalizados; oferecer um ambiente favorável para sua recuperação junto a sua família e orientá-la quanto à saúde de seu filho. Faz parte de um hospital-escola desde 1990, quando foi assinado o termo de Cessão de uso - Instituto Nacional de Assistência Medica da Previdência Social/Ministério da Saúde/Universidade de Brasília (INAMPS/ MS/ UnB) 01/90. O HUB conta atualmente com 289 leitos e 121 salas de ambulatório, tendo 33 especialidades médicas. O hospital atua junto à comunidade nos níveis primário (prevenção), secundário (atendimento de média complexidade) e terciário (atendimento de alta complexidade), e desenvolve trabalhos de ensino, pesquisa, assistência e extensão. Recebe pacientes do Plano Piloto e demais regiões administrativas, do entorno e outras unidades da Federação, além do fato de ser considerado referência para a população indígena. 
O HUB possui Divisão de Nutrição subdividida em: Centro de Produção de Refeições e Centro de Nutrição Clínica, o primeiro conta com quatro nutricionistas responsáveis pela solicitação, armazenamento e utilização de gêneros, preparo, distribuição e acondicionamento de refeições; o segundo com dezesseis nutricionistas responsáveis pelo atendimento dietoterápico, atividades de avaliação nutricional, discussão e evolução de casos, prescrição e orientação pós alta dentre outros.

A UPC/HUB, por sua vez, conta com 17 leitos, atende crianças e adolescente até 18 anos 11 meses e 29 dias e atende as seguintes especialidades médicas: pneumologia, gastrenterologia, nefrologia, neurologia, hematologia cardiologia, entre outras. É permitida a permanência de outros membros da família como acompanhantes, não se restringindo à figura da mãe e preserva-se a especificidade de cada caso, atendendo às demandas diferenciadas dos acompanhantes sempre que possível.

A visita às crianças segue as normas do hospital, em horários das $15 \mathrm{~h}$ às $16 \mathrm{~h}$ diariamente. Realizam visitas clínicas diárias aos leitos com a equipe de saúde para discussão diagnóstica e tratamento. A visita ocorre na presença do acompanhante, fato que permite maior esclarecimento, propiciando a troca de informações entre equipe/ hospitalizado/ acompanhante.

\subsection{Análises dos Dados}

A análise do material obtido segundo Minayo (2008) tem os seguintes objetivos de ultrapassar a incerteza, enriquecer a leitura e integrar as descobertas. É a fase em que se amplia a compreensão de contextos culturais.

Os dados resultantes da entrevista estruturada foram processados em uma planilha de banco de dados Statistical Package for Social Sciences SPSS versão 15 adaptado aos objetivos da pesquisa e passaram por uma análise estatística de forma a consolidar e obter uma visão mais ampla do processo de hospitalidade na unidade pesquisada. 


\section{RESULTADOS E DISCUSSÃO}

Com o principal foco da pesquisa na hospitalidade buscou-se conhecer o perfil dos entrevistados considerando: sexo, idade, grau de instrução, procedência, número de pessoas na família, número de pessoas que trabalham na família, renda familiar, tempo de hospitalização e número de hospitalizações para conhecer o perfil dos repondentes é importante para melhor compreensão das respostas obtidas.

\subsection{Perfil do respondente}

Com relação ao sexo a população entrevistada em sua maioria $(87,5 \%)$ é do sexo feminino. Este resultado leva a se pensar na manutenção do vínculo materno (CRISTO, 1999) refere que a mãe acredita ser ela a responsável pelo cuidado da criança. Entretanto, já é possível observar a presença de acompanhantes masculinos (12,5\%), como mostra a Figura 1.

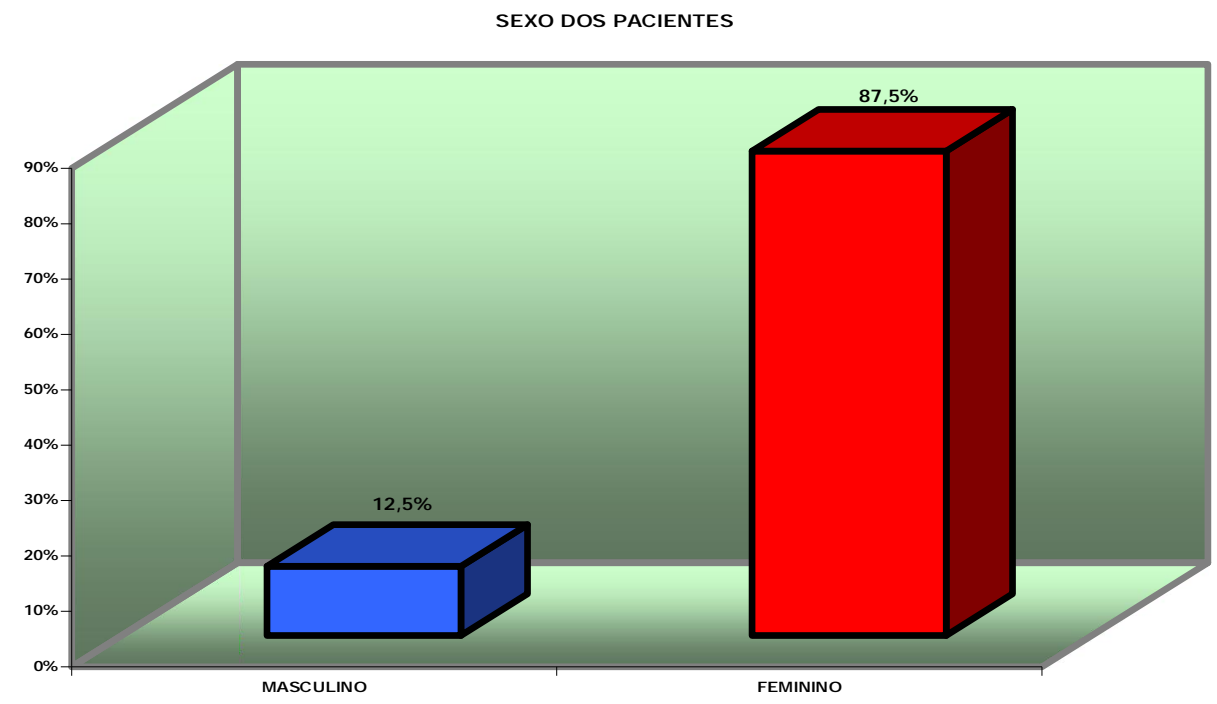

Figura 1: Perfil do entrevistado - Sexo

Com relação à faixa etária houve predominância entre 31 a 40 anos $(52,4 \%)$. A pesquisadora acredita que um dos motivos está relacionado ao fato do local do estudo atender adolescentes com até 19 anos incompletos, filhos de mães e pais acompanhantes com faixa etária compatível, conforme a Figura 2. 


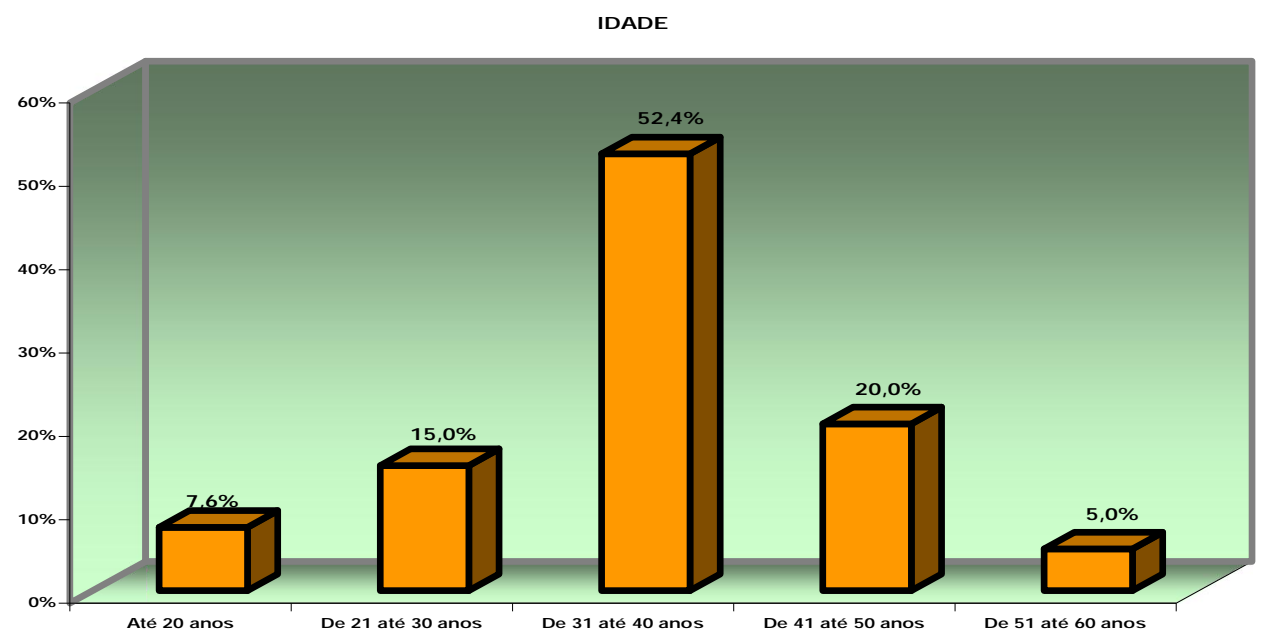

Figura 2: Perfil do entrevistado - Idade

Quanto o grau de escolaridade (Figura 3), prevaleceram o Ensino Fundamental incompleto (30\%) e o Ensino Médio completo (27,5\%), seguidos do Ensino Médio incompleto $(22,5 \%)$.

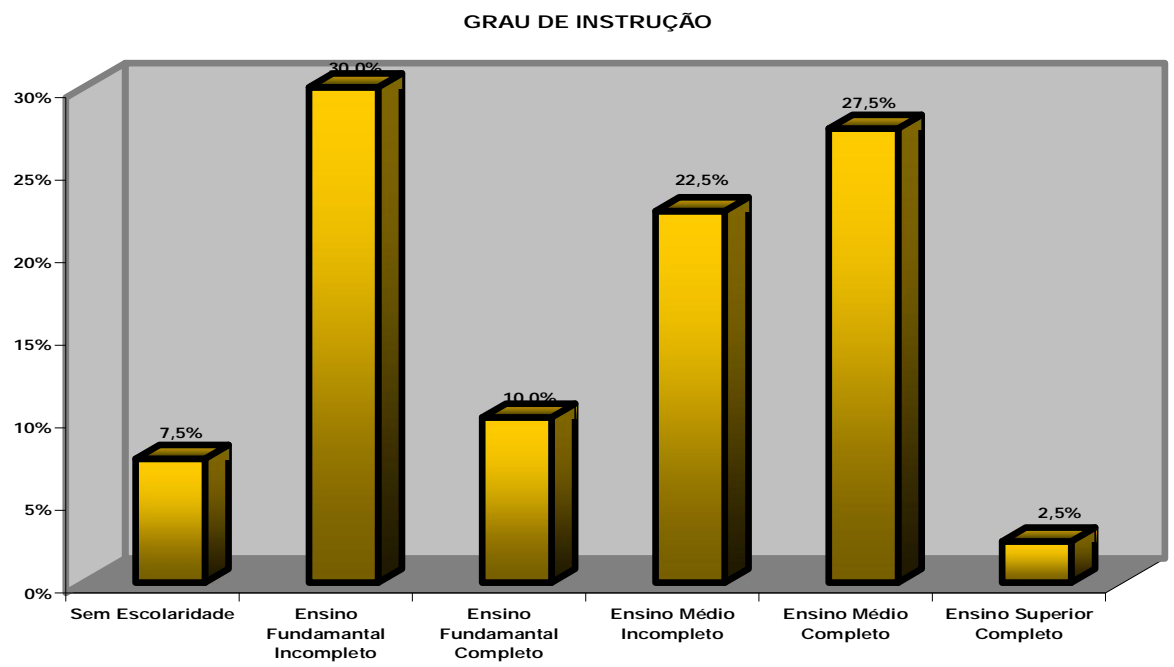

Figura 3: Perfil do entrevistado - Grau de instrução

Os dados levantados mostram que a maioria $(92,3 \%)$ dos respondentes não residem na região administrativa do Plano Piloto; 46,2\% residem nas outras regiões administrativas antes denominadas cidades satélites: Taguatinga, Sobradinho, Riacho Fundo, Ceilândia, entre outras; $25,6 \%$ vêm do entorno, cidades vizinhas ou limítrofes do Distrito 
Federal: Águas Lindas, Planaltina de Goiás, Cidade Ocidental, Unai, Santo Antonio do Descoberto, entre outras; e 20,5\% vêm de cidades de outros estados: Barreiras (BA), Imperatriz (MA), Rondônia, dentre outros (Figura 4). Observou-se o baixo percentual $(7,7 \%)$ de residentes do Plano Piloto.

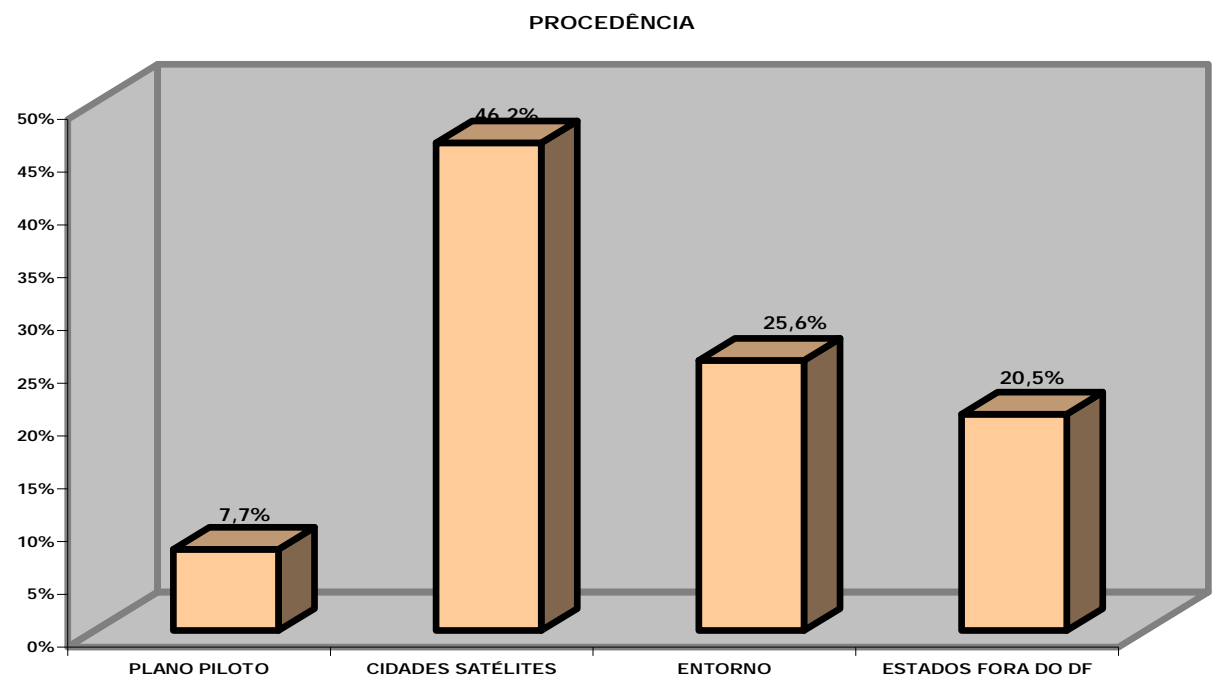

Figura 4: Perfil do entrevistado - Procedência

Com relação a renda familiar ficou constatado que 50\% recebem entre 1 a 2 salários mínimos (Figura 5). Notou-se que 90\% dos entrevistados responderam ter renda familiar abaixo de um salário mínimo e no máximo 4 salários mínimos. Esses dados podem ter relação com o grau de escolaridade. 


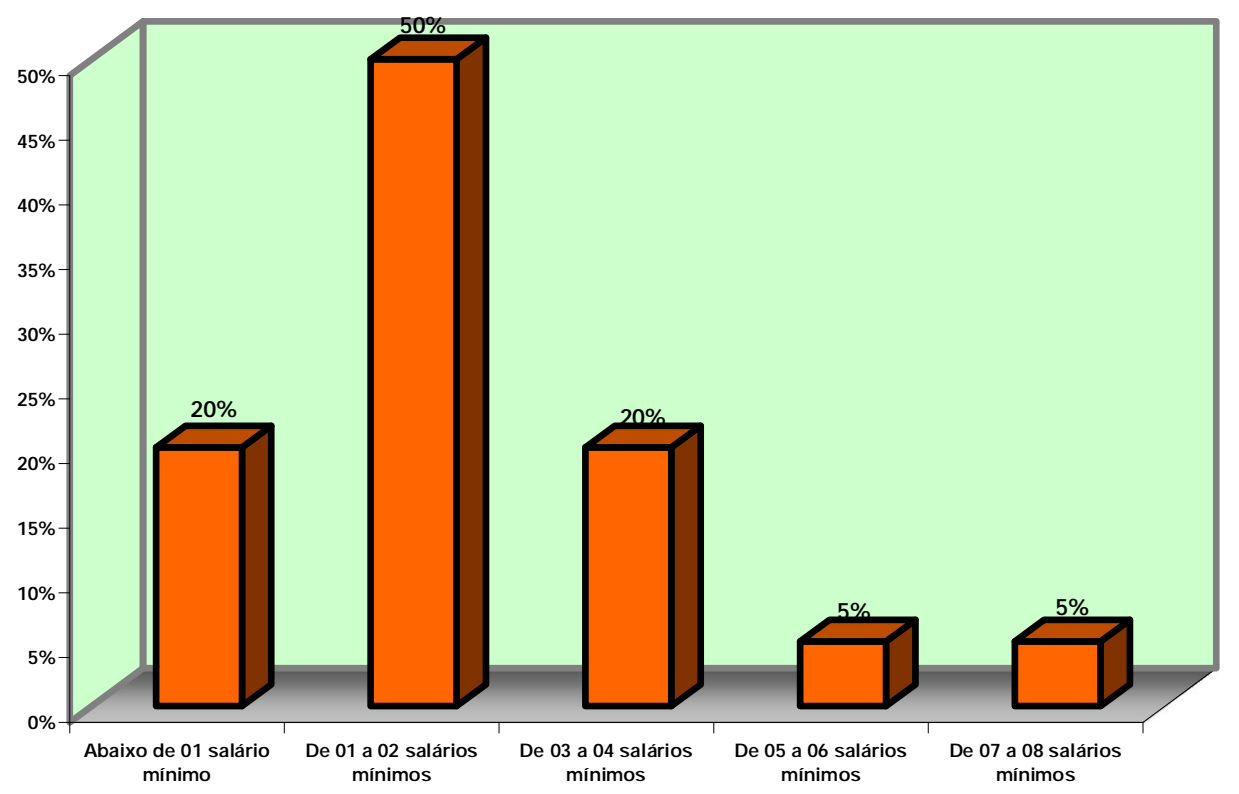

Figura 5: Perfil do entrevistado - Renda familiar

Quanto ao número de pessoas que trabalham na família observa-se que em 62,5\% das respostas somente uma pessoa trabalha, o que pode estar associado também à renda familiar entre um a dois salários mínimos como mostra a Figura 5.

NÚMERO DE PESSOAS QUE TRABALHAM NA FAMÍLIA

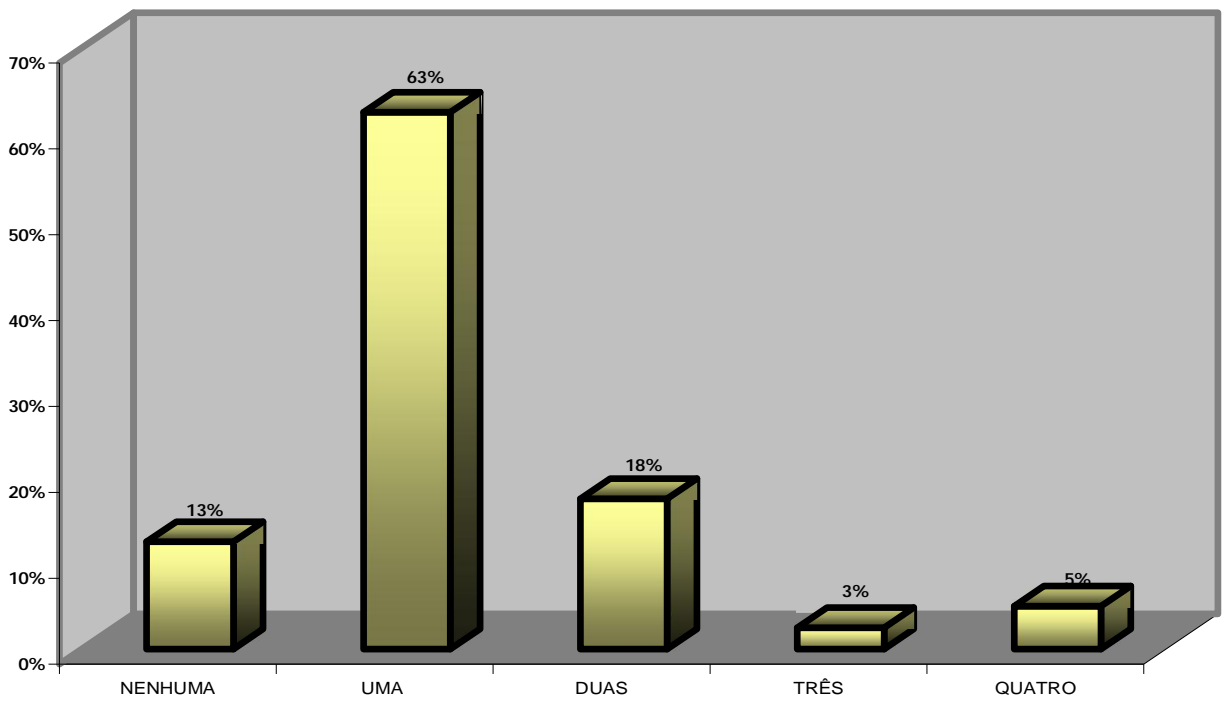

Figura 6: Perfil do entrevistado - número de pessoas que trabalham na família 
A constituição familiar é formada por 02 a 05 membros $(82,5 \%)$ e por 06 a 08 (17,5\%). Segundo o IBGE (2001) o número de pessoas por família diminuiu em todas as regiões brasileiras. A média nacional em 2001 foi de 3,3 pessoas por família, ou seja, os resultados encontrados no estudo corroboram essa média, como ilustra a Figura 7.

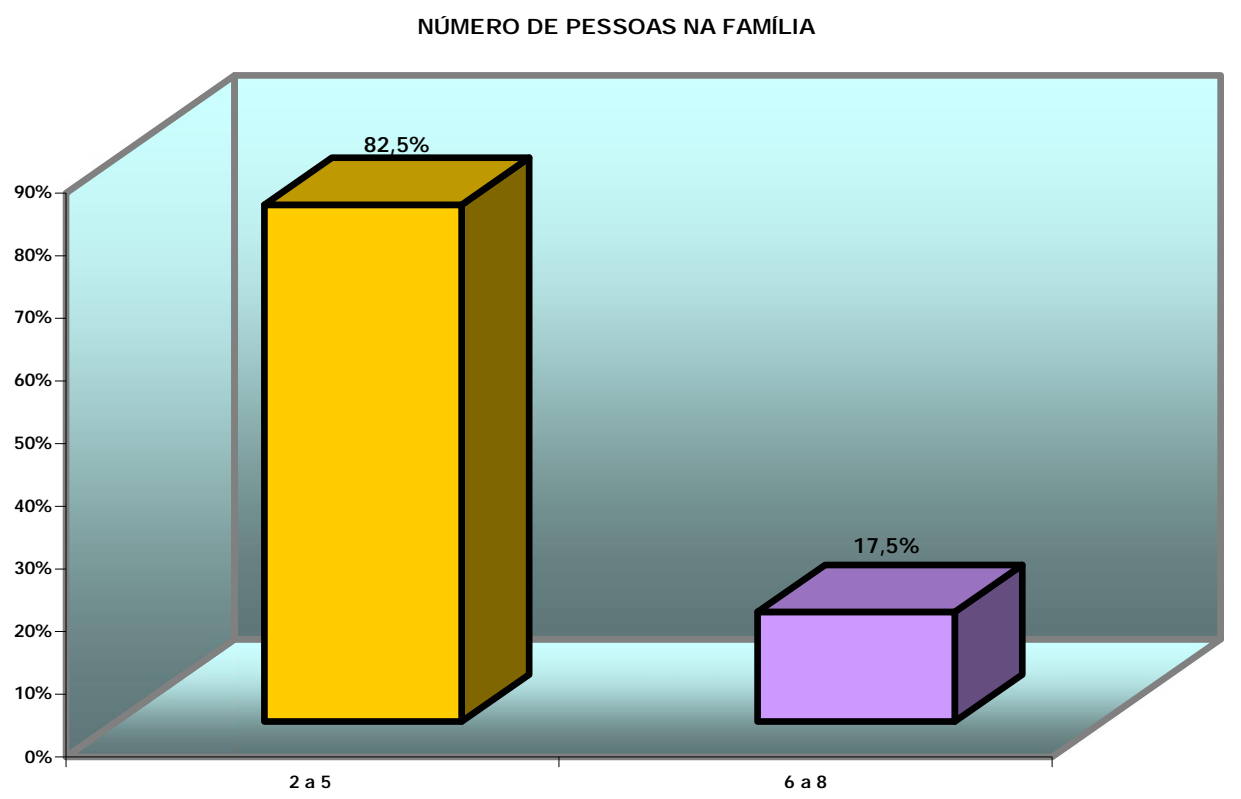

Figura 7: Perfil do entrevistado - número de pessoas na família

Com referência ao tempo de hospitalização, 62,5\% das pessoas entrevistadas permaneceram entre 02 e 05 dias, 22,5\% entre 6 e 10 dias, e $15 \%$ acima de 11 dias (Figura 8). Um censo realizado nos registros da Unidade em julho de 2009 comprova esses dado: a média de permanência na UPC situou-se em 4,1dias. 


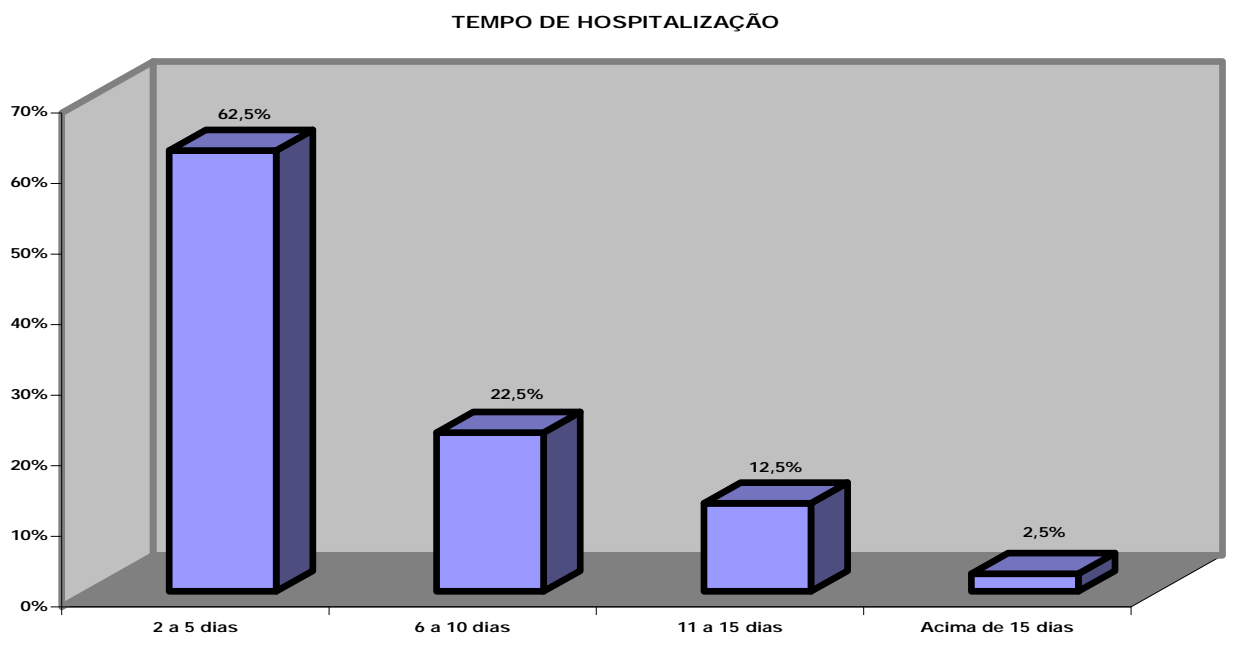

Figura 8: Perfil do entrevistado - tempo de hospitalização

Em relação ao número de hospitalizações prevaleceu a primeira internação (47\%) (Figura 9), diante deste resultado evidencia se a necessidade dos profissionais de saúde estarem capacitados para o real acolhimento das crianças em um momento tão marcante nas suas vidas e nas de seus familiares.

Observou-se que os números de 2 a mais de 5 internações, somados, equivalem-se ao da primeira hospitalização, o que reforça a necessidade de capacitação da equipe.

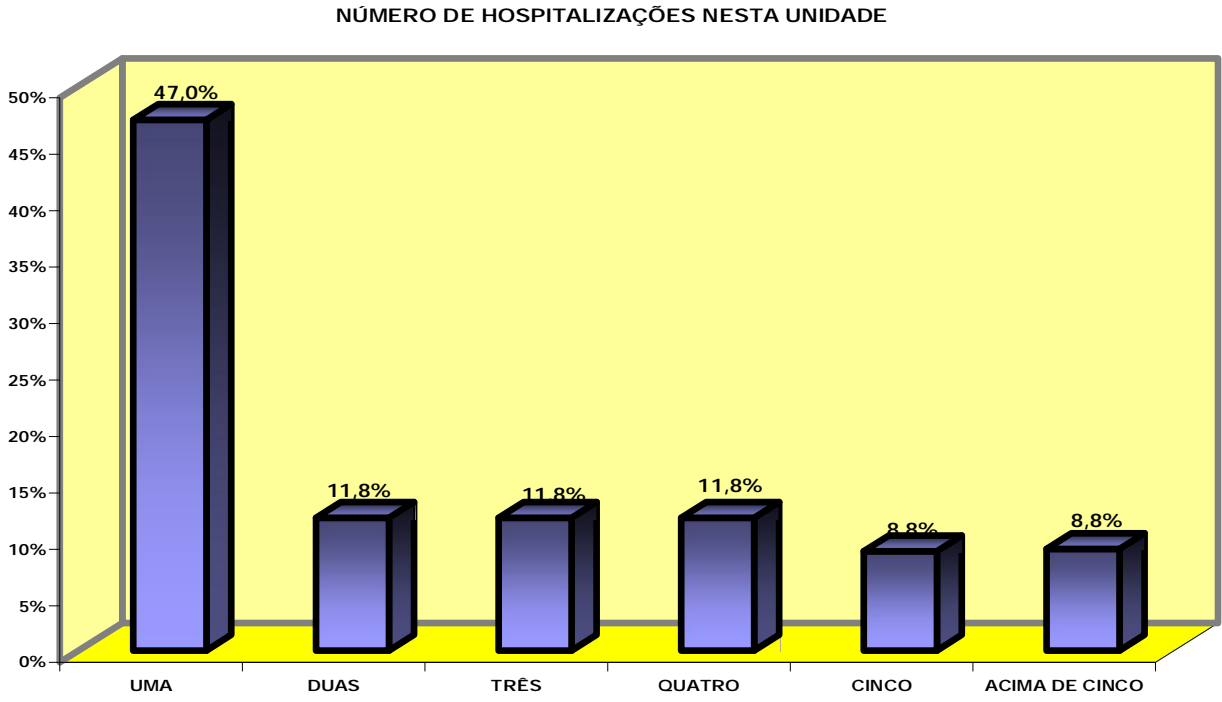

Figura 9: Perfil do entrevistado - número de hospitalizações 


\subsection{Qualidades dos Serviços e Instalações}

$\mathrm{O}$ instrumento de avaliação determinou os seguintes parâmetros: muito fraco-MF, fraco-F, regular-R, bom-B, muito bom-MB, e não teve como avaliar - NA.

O Quadro 1 sistematiza as respostas obtidas para as variáveis: acesso e presteza ao atendimento (rapidez na hospitalização, acesso dos acompanhantes, acesso dos familiares nos horários de visita; troca de acompanhante; atendimento e orientação sobre o funcionamento da unidade) e os dados registrados para a questão qualidades dos serviços e instalações.

A avaliação do acesso e presteza do atendimento foi predominantemente boa e muito boa $(78 \%)$, ou seja, esses aspectos foram considerados de forma geral, adequados às necessidades dos entrevistados.

Quadro 1: Acesso e presteza ao atendimento

\begin{tabular}{|c|c|c|c|c|}
\hline \multicolumn{2}{|c|}{ Validade } & Frequência & Percentual & $\begin{array}{c}\text { Validade } \\
\text { Percentual }\end{array}$ \\
\hline & Muito fraco & 4 & 2,0 & 2,0 \\
\hline & Fraco & 6 & 3,0 & 3,0 \\
\hline & Regular & 13 & 6,5 & 6,6 \\
\hline & Bom & 94 & 47,0 & 47,7 \\
\hline & Muito Bom & 62 & 31,0 & 31,5 \\
\hline & $\begin{array}{l}\text { Não tenho como } \\
\text { avaliar }\end{array}$ & 18 & 9,0 & 9,1 \\
\hline & Total & 197 & 98,5 & 100,0 \\
\hline Não & Responderam & 3 & 1,5 & \\
\hline Total & & 200 & 100,0 & \\
\hline
\end{tabular}

Quanto a instalações, equipamentos auxiliares nos cuidados e tratamento dos hospitalizados da UPC (aparência da unidade; funcionamento dos equipamentos; conforto nas instalações físicas; quantidade e qualidade de roupas de cama e banho; nível de silêncio; 
qualidade das refeições oferecidas ao acompanhante e paciente; acesso ao telefone; espaço para atividades; mobiliário), o Quadro 2 mostra os resultados obtidos: bom (40\%), muito bom $(21,4 \%)$, totalizando $61,4 \%$ das respostas. Notou-se que seria necessário somar os valores para regular $(15,6 \%)$, fraco $(8,3 \%)$ e muito fraco $(7,8 \%)$ para se alcançar apenas a metade do valor obtido para bom e muito bom.

Quadro 2: Instalações, equipamentos auxiliares nos cuidados e tratamento dos hospitalizados

\begin{tabular}{|cl|c|c|c|}
\hline Validade & Frequência & Percentual & $\begin{array}{c}\text { Validade } \\
\text { Percentual }\end{array}$ \\
\hline Muito fraco & 28 & 7,8 & 8,0 \\
Fraco & 30 & 8,3 & 8,5 \\
Regular & 56 & 15,6 & 15,9 \\
& Bom & 144 & 40,0 & 40,9 \\
& Muito Bom & 77 & 21,4 & 21,9 \\
& Não tenho como & 17 & 4,7 & 4,8 \\
& avaliar & 352 & 97,8 & 100,0 \\
Total & 8 & 2,2 & \\
Não & Responderam & 360 & 100,0 & \\
\hline
\end{tabular}

Em relação à equipe médica e de enfermagem, foram pesquisadas as seguintes variáveis: formas de identificação pessoal; gentileza; interesse e atenção ao caso do cliente; compreensão das necessidades do acompanhante; privacidade no atendimento; informações claras e precisas sobre o diagnóstico e tratamento. Obteve-se como resultado um grau de satisfação considerado muito bom no desempenho das equipes $(50,7 \%)$, de acordo com Figura 10 e somados aos $38,3 \%$ de avaliação como "bom", tem $89 \%$ de satisfação. Portanto, as pessoas que participaram do estudo relataram uma boa relação com os profissionais de saúde, 
o que confirma que acolher pessoas em busca de auxilio à saúde implica sempre em relação humana que deve agregar não só eficiência, mas respeito à singularidade do cliente de saúde.

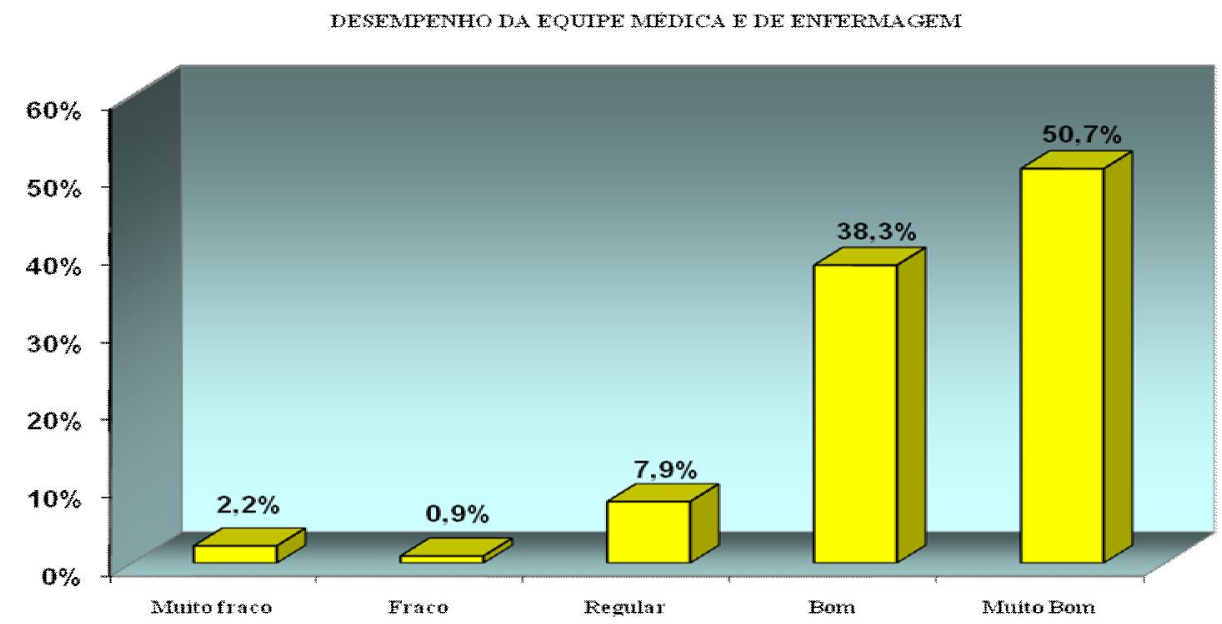

Figura 10: Qualidades dos serviços e instalações- Desempenho da equipe médica e de enfermagem

Com referência à equipe de pedagogia e recreação foram avaliadas as variáveis: identificação pessoal, gentileza; interesse e atenção ao caso do cliente; compreensão das necessidades; privacidade no atendimento; informações claras e precisas sobre atividade lúdica, brinquedoteca na recuperação da criança; atividades pedagógicas. A maioria considerou essas variáveis como boas e muito boas $(77,4 \%)$, como mostra a Figura 11 . Na UPC/HUB há um espaço onde são desenvolvidas atividades lúdico-pedagógicas, tais como: pinturas, desenhos, narração de histórias, apresentações teatrais, confecção de brinquedos, organização de painéis e festas comemorativas, além da brinquedoteca, o que deve ter contribuído para os resultados dessa avaliação. 


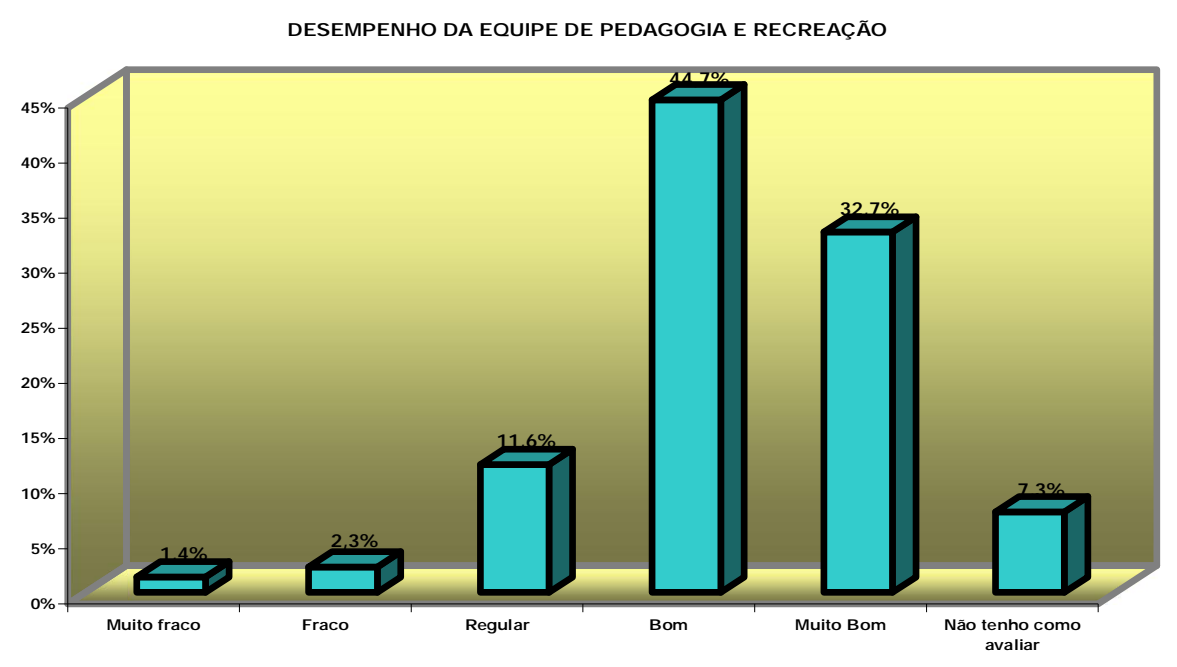

Figura 11: Desempenho da equipe de Pedagogia e Recreação

Em relação à avaliação da equipe de nutrição as variáveis pesquisadas foram: identificação pessoal, gentileza, interesse e atenção ao caso do cliente, compreensão das necessidades dos acompanhantes, privacidade no atendimento, informações claras e compreensivas com relação à alimentação oferecida; respeito, compreensão com relação aos costumes e culturas alimentares; orientação nutricional pós alta. As opções bom e muito bom estiveram em $78 \%$ das respostas (Figura 12).

Foi feita uma visita técnica à cozinha do HUB em companhia da nutricionista Juliana Rolin Vieira Maciel da UPC/HUB em 06/08/2009, pode-se constatar as dificuldades do setor como: lavagem de louças e legumeiras ainda manuais. Possuem apenas duas câmaras frigoríficas em funcionamento (uma exclusiva para carnes e outra para frutas e verduras, laticínios, entre outros).

Não existe carro aquecido para distribuição das dietas, o que contribui para a chegada da alimentação em temperatura inadequada nas unidades. Vale ressaltar ainda que a compra dos insumos depende de licitações que requerem tempo para análise das propostas e aprovação, o que ocasiona atrasos e pode influenciar na qualidade dos produtos, pois, em alguns casos, tornam-se necessárias compras emergenciais. Contudo, vale ressaltar que apesar 
dessas dificuldades como ficou demonstrado, o desempenho da equipe foi considerado adequado.

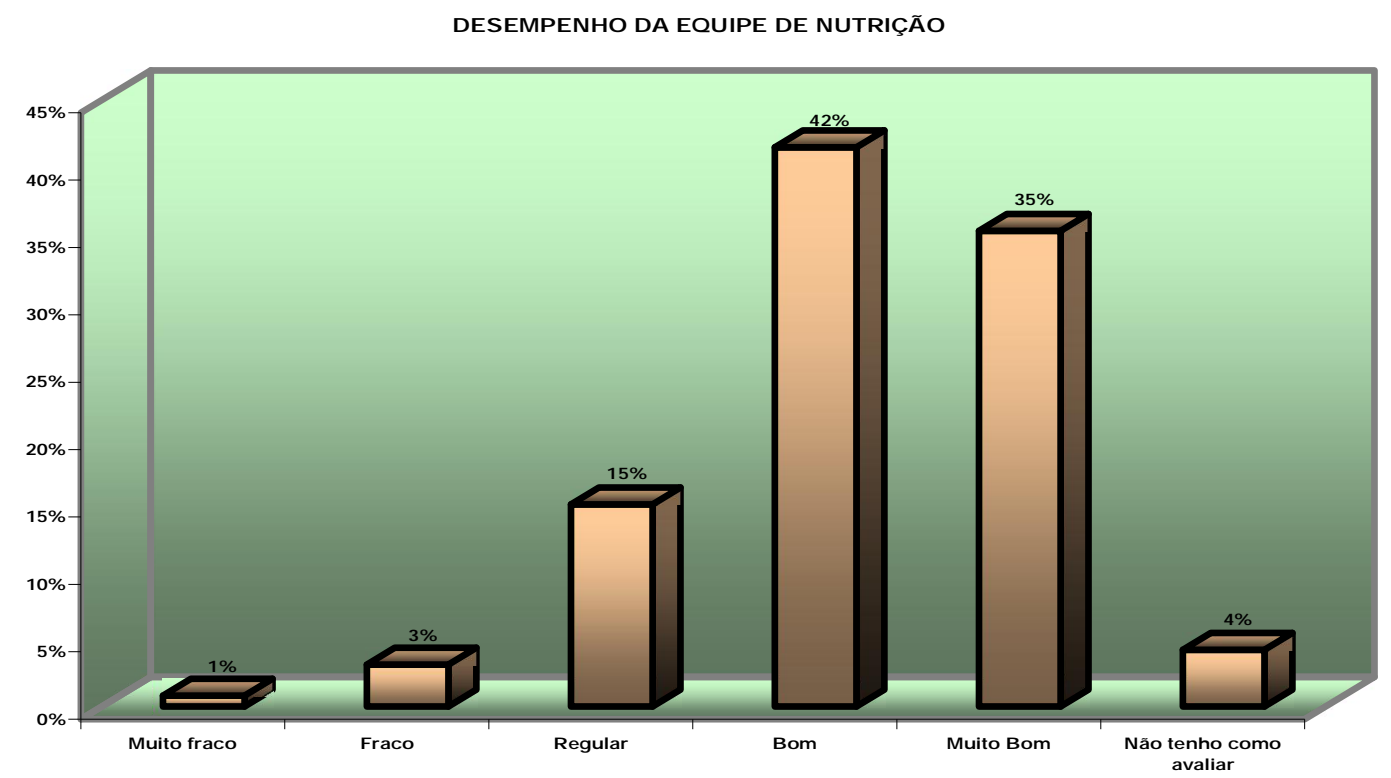

Figura 12: Desempenho da equipe de Nutrição

\subsection{Itens mais importantes}

Com a finalidade de compreender melhor o que os entrevistados consideram como itens prioritários no funcionamento do atendimento, instalações e equipamentos da UPC/HUB selecionou-se seis questões com variáveis contidas nas questões anteriores, como se mostra a seguir:

\subsubsection{Presteza dos serviços:}

O Quadro 3 mostra que a facilidade de vaga para internação e a rapidez na realização dos exames são os itens prioritários no quesito "acesso". Isto pode ser interpretado como o desejo do cliente ter seu problema resolvido e consequentemente o retorno ao seu ambiente familiar o mais rápido possível. 
Quadro 3: Acesso e presteza dos serviços

\begin{tabular}{|c|c|c|c|}
\hline Validade & Freqüência & $\begin{array}{c}\text { Porcentagem } \\
(\%)\end{array}$ & Percentagem Válida (\%) \\
\hline $\begin{array}{l}\text { Facilidade de vaga } \\
\text { para a internação }\end{array}$ & 34 & 42,5 & $43,6 \%$ \\
\hline $\begin{array}{l}\text { Facilidade e rapidez } \\
\text { para a realização de } \\
\text { exames }\end{array}$ & 23 & 28,8 & $29,5 \%$ \\
\hline $\begin{array}{l}\text { Facilidade e rapidez } \\
\text { na entrega dos } \\
\text { resultados de exames }\end{array}$ & 8 & 10,0 & $10,3 \%$ \\
\hline $\begin{array}{l}\text { Facilidade em } \\
\text { receber informações } \\
\text { sobre exames } \\
\text { realizados }\end{array}$ & 13 & 16,3 & $16,6 \%$ \\
\hline Total & 78 & 97,5 & 100 \\
\hline Não responderam & 2 & 2,5 & \\
\hline Total & 80 & 100,0 & \\
\hline
\end{tabular}

\subsubsection{Clareza das Informações:}

No Quadro 4 ficou evidente o quanto são importantes a informação clara e compreensiva do diagnóstico e tratamento, a identificação dos profissionais e as orientações após a alta. Pode-se deduzir que quem é acolhido quer ser bem informado a respeito do tratamento e conhecer os profissionais com os quais interage e se interessa pelos procedimentos posteriores. 
Quadro 4: Clareza de Informações

\begin{tabular}{|l|c|c|c|}
\hline \multicolumn{1}{|c|}{ Validade } & Frequência & $\begin{array}{c}\text { Porcentagem } \\
(\%)\end{array}$ & $\begin{array}{c}\text { Percentagem Válida } \\
(\%)\end{array}$ \\
\hline $\begin{array}{l}\text { Identificação clara dos } \\
\text { profissionais }\end{array}$ & 22 & 27,5 & $28,9 \%$ \\
$\begin{array}{l}\text { Informações claras e } \\
\text { compreensíveis dadas } \\
\text { sobre o diagnóstico e } \\
\text { tratamento do } \\
\text { hospitalizado }\end{array}$ & 26 & 32,5 & $34,3 \%$ \\
$\begin{array}{l}\text { Orientações sobre a } \\
\text { continuação do tratamento } \\
\text { pós alta }\end{array}$ & 19 & 23,8 & $25,0 \%$ \\
$\begin{array}{l}\text { Informações Claras sobre } \\
\text { a prevenção de doenças e } \\
\text { outros assuntos educativos } \\
\text { para a saúde }\end{array}$ & 9 & 11,3 & $11,8 \%$ \\
$\begin{array}{l}\text { Total } \\
\text { Não responderam }\end{array}$ & 76 & 95,0 & 100,0 \\
\multicolumn{1}{c}{ Total } & 80 & 100,0 & \\
\hline
\end{tabular}

\subsubsection{Qualidade da relação com os profissionais:}

Nesta questão foram considerados pelos entrevistados como os três pontos prioritários: o interesse e a atenção ao caso clínico, (30,8\%); a gentileza (29,5\%); e informações claras e compreensíveis sobre o tratamento $(23,1 \%)$. Esses dados confirmam a hospitalidade como o ato de abrigar e receber bem (Figura 13). 


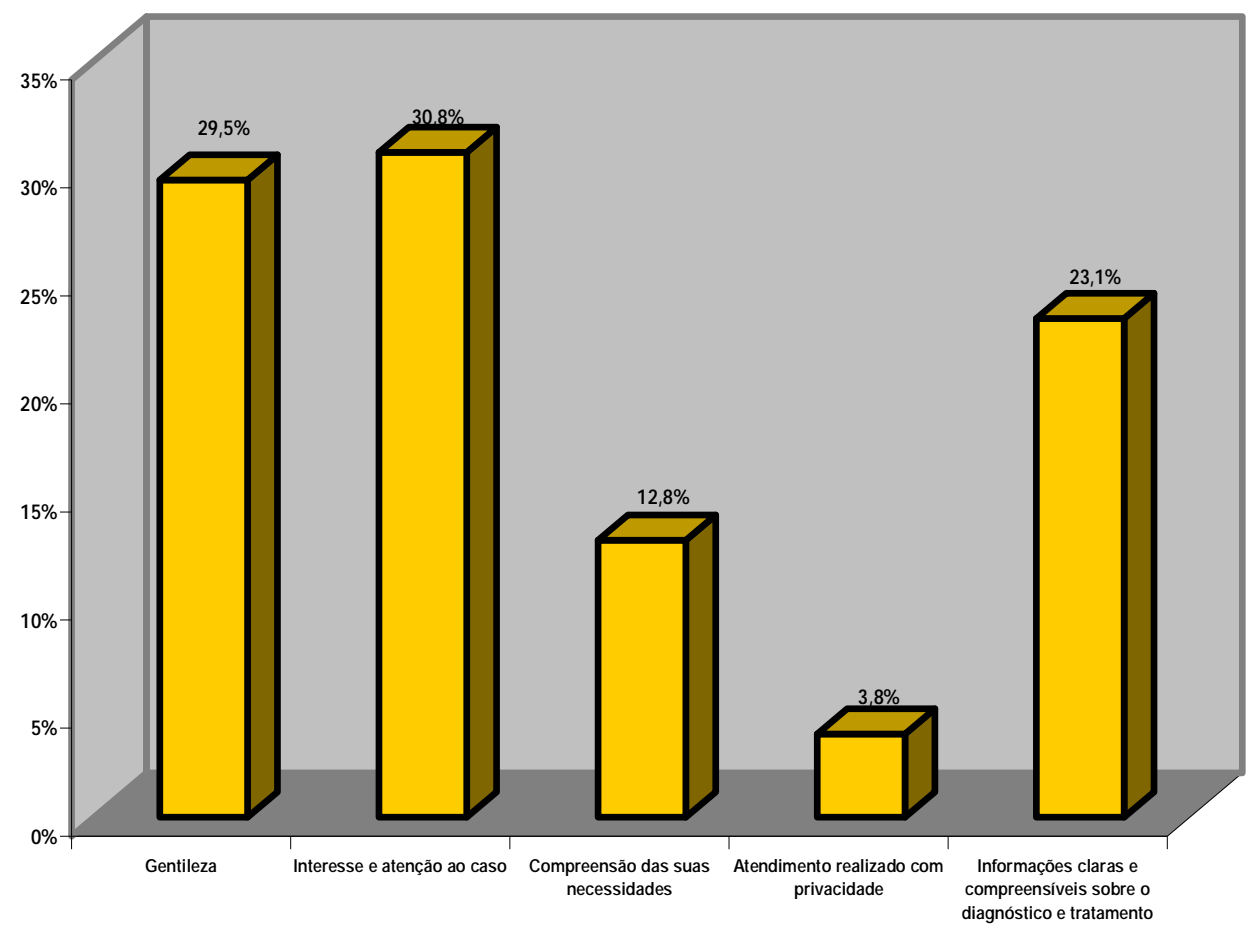

Figura 13: Qualidade da relação com os profissionais

\subsubsection{Qualidades dos Equipamentos:}

Nesta questão o funcionamento dos equipamentos foi destaque $(37,2 \%)$, seguida pelas refeições com qualidade $(29,5 \%)$ e roupas de cama e banho com boa quantidade e qualidade $(21,8 \%)$. Fica evidente que a tecnologia está presente em tudo que fazemos e na área hospitalar contribui para o diagnóstico e tratamento dos clientes de saúde (Figura 14). Quanto à refeição com qualidade, os resultados vem reafirmar o que Camargo (2005) afirma sobre não se poder deixar de lado o contexto higiene e qualidade alimentar, ainda que este alimento seja simbólico sob a forma de um copo de água. Pode-se também citar Boeger (2004) para quem a gastronomia hospitalar é a arte de integrar a patologia do hospitalizado com a dieta individualizada, com arte e técnica pode-se tornar um prazer o momento da alimentação. 


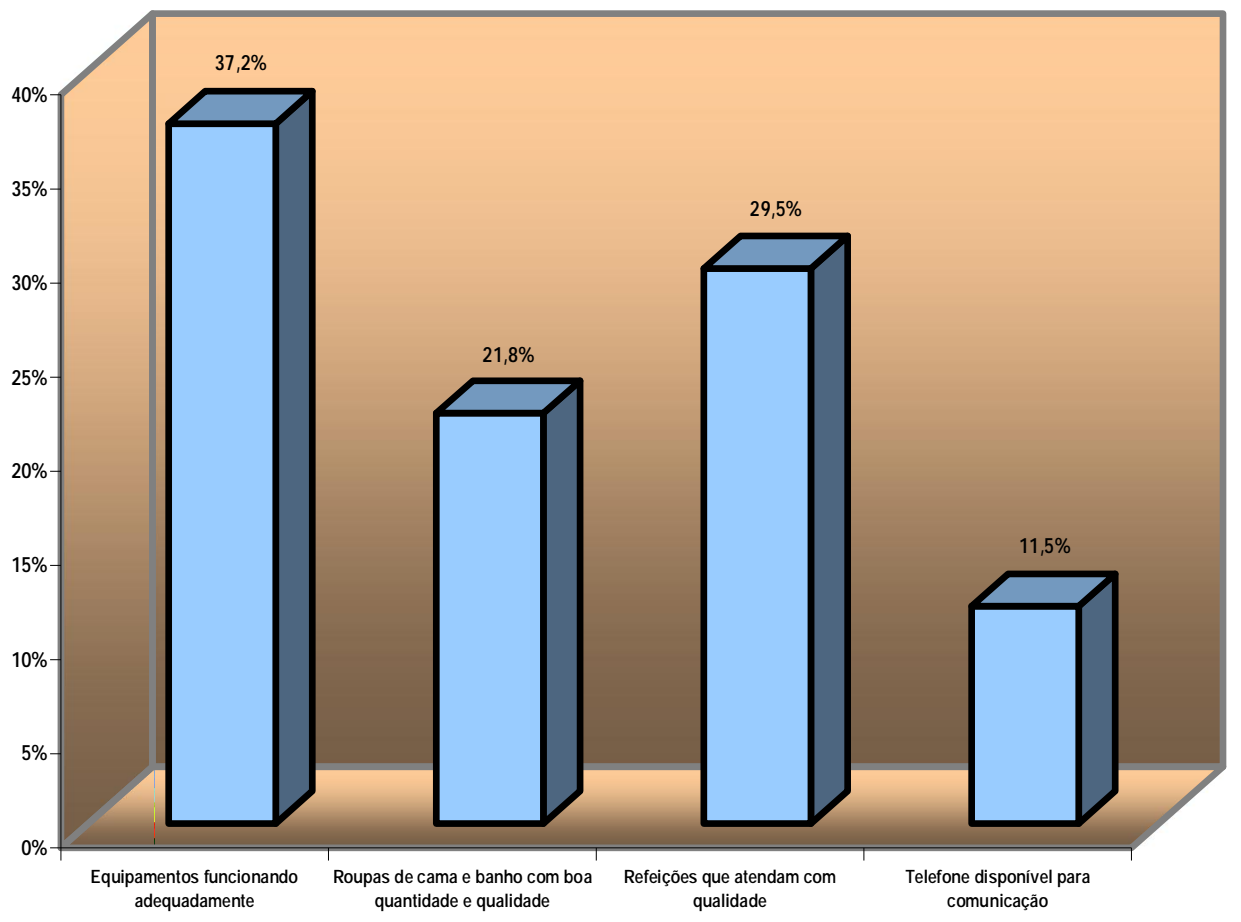

Figura 14: Qualidade dos equipamentos e alimentação

\subsubsection{Qualidades das instalações}

Neste item procurou-se saber sobre a higienização adequada de quartos e banheiros, sinalização bem localizada e fácil de ser entendida, quartos e banheiros confortáveis, nível de silêncio adequado e espaço para atividades. Como mostra a Figura 15, obteve-se como os três itens mais importantes: higienização adequada de quartos e banheiros $(29,9 \%)$; mobiliário confortável (22,1\%); espaço para as atividades de convivência $(19,5 \%)$.

A construção da unidade pesquisada é de 1972, época em que as unidades hospitalares não recebiam acompanhantes, só a partir da Lei 8069/90, referida em capítulo anterior, tornou-se obrigatoriedade a presença de familiares aos menores hospitalizados, realidade que obrigou os dirigentes a fazer adaptações que, por vezes, não oferecem o conforto desejado pelos usuários conforme se demonstrou com a pesquisa. 


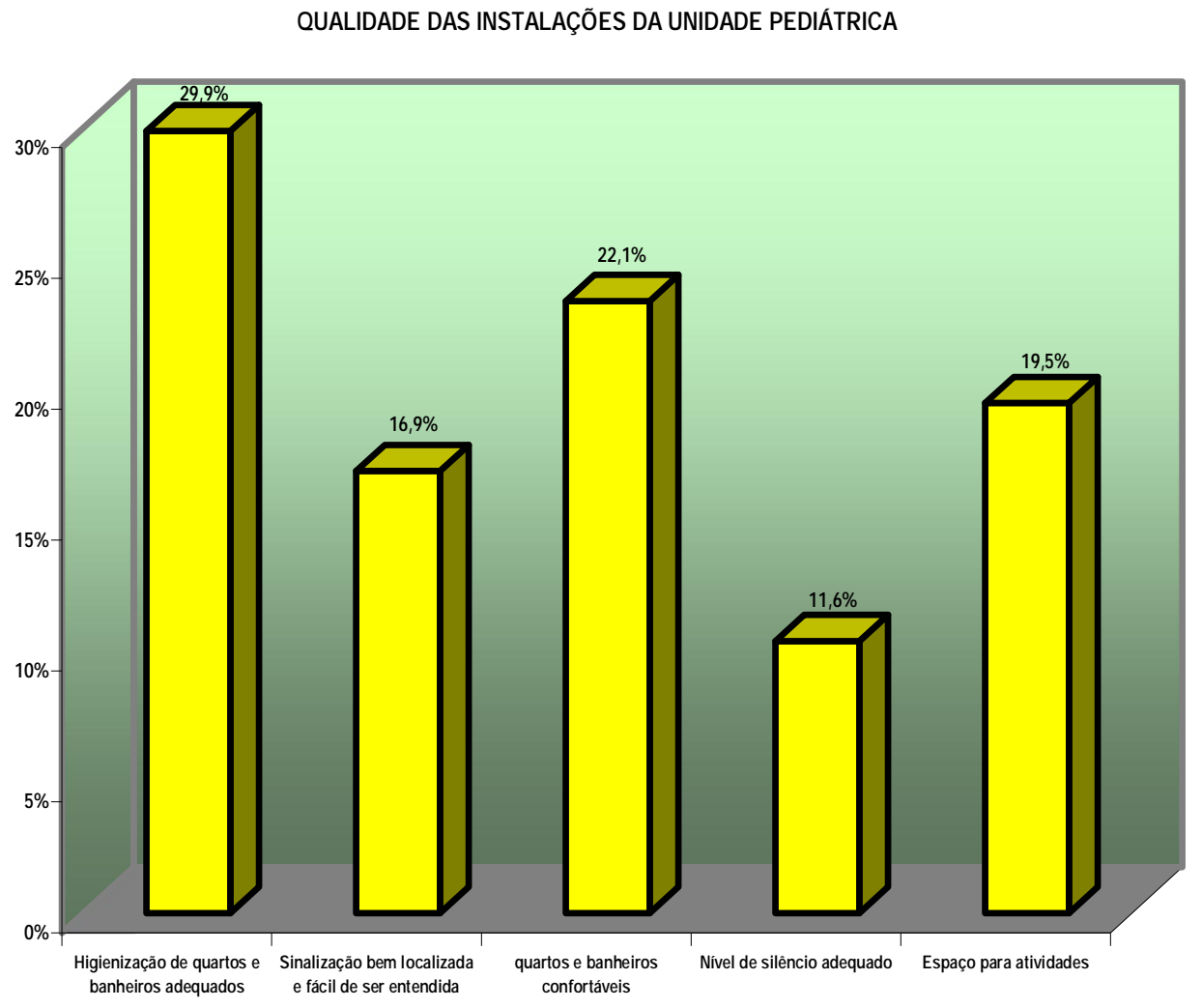

Figura 15: Qualidade das instalações da Unidade Pediátrica

\subsubsection{Qualidades de atendimento ao acompanhante:}

$\mathrm{O}$ item mais importante considerado nesta questão foi: refeições para os acompanhantes (32\%). Os itens número de acompanhantes por cliente e mobiliarios confortaveis (camas, cadeiras, armários, entre outros) tiveram a mesma importância $(23,1 \%)$, seguidos do item facilidade para o acesso $(21,8 \%)$. Como já foi mencionado anteriormente, o hospital recebe mais de $90 \%$ de pessoas residentes fora do Plano Piloto, portanto receber alimentação é indispensavel para quem mora distante de seu domicílio. 


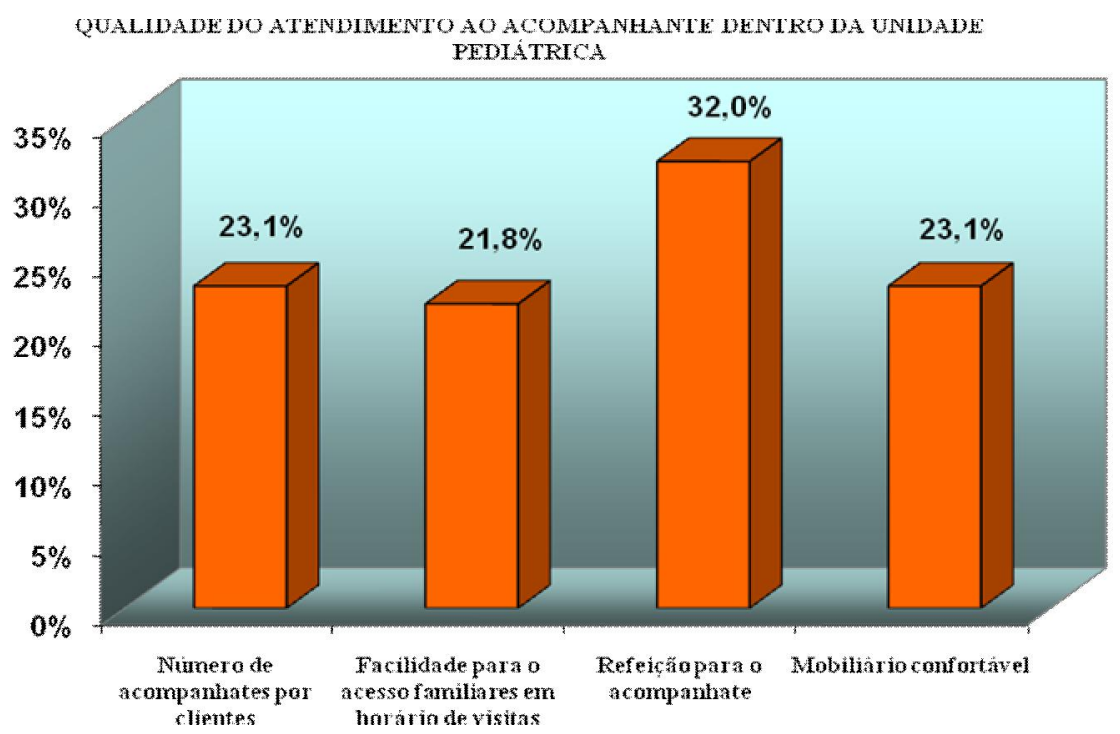

Figura 16: Qualidade do atendimento ao acompanhante

\subsection{Informações complementares}

Nesta parte do questionário foram feitas três perguntas abertas: 1) O horário de visitas atende às necessidades da pessoa hospitalizada e dos familiares e amigos?; 2) O Sr./Sra Gostaria de fazer algum outro comentário sobre a maneira como foi atendido (a) nesta Unidade Pediátrica?; e 3) $\mathrm{O} \mathrm{Sr} . / \mathrm{Sr}^{\mathrm{a}}$. gostaria de fazer algum outro comentário sobre o funcionamento da Unidade de Pediatria Clínica?. Nelas o entrevistado poderia acrescentar comentários que, a seu ver, não haviam sido solicitados.

4.4.1 Os entrevistados, em suas falas a respeito do horário de visitas do hospital (pergunta 1), podem ser representados pelas seguintes colocações (selecionadas para exemplificar o todo):

\footnotetext{
Apesar de pouco tempo, eu acredito que sim, até mesmo porque se tivesse tempo de visitas maiores, estaríamos contribuindo para infecções, já que muitas pessoas não tomam as devidas precauções a fazer visitas pros pacientes (Entrevistado 5).

Sim, mas porque nos finais de semana o horário não é ampliado para 2 horas (Entrevistado 8).

Sim, mas somente em alguns casos, pois quem mora longe não tem como visitar neste horário, e muitas vezes eles não entendem isso (Entrevistado 16).
} 
Acho o horário de visitas muito pouco e só pode entrar uma pessoa ao invés de uma poderia ser 2 pessoas para que todas as visitas possam entrar para visitar (Entrevistado 29).

\subsubsection{Quanto à pergunta 2, a maneira como foi atendido (a) na Unidade Pediátrica, foram} selecionadas, como amostragem, as seguintes respostas:

$\mathrm{O}$ atendimento realmente não tem queixa a atenção dos profissionais aos pacientes é muito grande, a presença é sempre constante, sem deixar o paciente desamparado. Sobre a equipe de nutrição seria muito bom ter a opção de caldo ou sopa na última refeição (Entrevistado 18).

Não, além de agradecer a deus e a esse pessoal que nos acolhe num momento em que estamos fragilizados e nossas crianças também, o atendimento é ótimo (Entrevistado 8).

Ao contrário de algumas dependências do hospital, aqui na pediatria, tanto eu, como meu filho nos sentimos confiantes e isso nos dá mais segurança, pois quando se tem a confiança na equipe, a recuperação é mais rápida, e os dias no hospital não se torna sóbrios, pois sempre tem u profissional para nos tranqüilizar e nos fortalecer. Sou muito grata à Deus por essa equipe geral (Entrevistado 5).

\subsubsection{Já com relação à pergunta 3 , que trata do funcionamento da Unidade de Pediatria}

Clínica, obtiveram-se as respostas abaixo exemplificadas:

Somente uma reforma nos móveis dos quartos, e uma pintura nova e mais desenhada nas paredes para ficar um ambiente aconchegante (Entrevistado 4).

O funcionamento da unidade é bom, podendo ser bem melhor, pois temos equipes excelentes, profissionais de grande força de vontade, mas do que vale tudo isso se as condições técnicas não são boas, falta muito pouco para deixarmos essa unidade bem melhor, falta uma união e cumplicidade de pacientes e equipes para fazer valer nossos direitos (Entrevistado 5).

Só não gostamos dos banheiros, pois não são espaçosos e o banho é quase sempre frio (Entrevistado 24).

Sim a rapidez do atendimento, e eficácia da equipe, pois menos que uma semana meu filho passou por exames, diagnóstico, e já entrou em tratamento, por essa razão acho que foi muito rápido, e muito diferente em relação a outros hospitais (Entrevistado 25).

Sim, foi regular, mas pode mudar e muito para a melhor, só depende do pessoal da direção do hospital, falta muitas coisas, que eles com um pouco de esforço, podem conseguir para melhorar o atendimento, estadia, consultas e exames que os pacientes têm direito (Entrevistado31).

Ao se avaliar todas as respostas observou-se que as variáveis "horário e tempo das visitas" receberam sugestões de ampliação, assim como o número de visitantes por vez. 
Quanto ao atendimento na UPC/HUB não houve críticas e demonstram grau alto de satisfação com o serviço. O funcionamento da unidade de modo geral recebeu críticas e sugestões tais como: banheiros mais confortáveis, pinturas e móveis novos, maior interação entre pacientes e a equipe multidisciplinar para propiciar uma relação mais solidária e humanizada.

Para Quevedo (2006) as instituições hospitalares não podem deixar em segundo plano os serviços que oferecem aos seus clientes. Deste modo, devem-se considerar fatores como regra especifica de cada área, porém, sem deixar de se preocupar com o ser humano seu enfoque principal, como preconiza a hospitalidade. 


\section{CONSIDERAÇÕES FINAIS}

A hospitalidade está inserida entre diversas áreas, entre elas, o ambiente hospitalar. O hospital é constituído por unidades que fazem parte do todo, cuja finalidade é receber, acolher aqueles que deixam suas casas, comunidades, e até seus estados e/ou país em busca de auxílio à saúde. $\mathrm{O}$ ato de hospedar em uma unidade de saúde caracteriza a hospitalidade como o elo que se estabelece entre os profissionais e cliente de saúde.

Partindo dessa premissa, a pesquisa realizada teve a participação de 40 acompanhantes respondentes ao questionário que possibilitou extrair informações, análisar e interpretar os dados. Obteve-se como resultado geral, atendimento multiprofissional considerado bom. Paralelamente, foi realizada também pesquisa documental a qual auxiliou no esclarecimento e compreensão de dúvidas quanto as variáveis pesquisadas: arquitetura foi o ponto crítico da pesquisa, caracterizada como uma construção antiga de 37 anos atrás que não oferece infra-estrutura em condições ideais de satisfazer a necessidade de conforto dos clientes enquanto hóspedes de saúde, espaço inadequado para acomodações, mobiliários velhos e desconfortáveis.

A Atividade Lúdica e Pedagógica apresenta um trabalho que oportuniza atividades em busca de socialização que possam contribuir para minimizar o estresse e auxiliar na recuperação da saúde dos hospitalizados, além de proporcionar sensações de segurança, alegria e prazer, possui um espaço com brinquedoteca e outras atividade recreativa, entretanto, não foi citada como item mais importante pelos entrevistados.

A alimentação está dentro dos padrões dietéticos estabelecidos para pessoas que merecem uma nutrição balanceada. Porém, sem o glamour gastronômico, pois, com o déficit de equipamentos adequados (carro aquecido para transporte dentre outros) e até mesmo de alguns insumos dificultam a Divisão de Nutrição, oferecer um serviço de maior e melhor qualidade, ainda assim, foi considerada como um dos itens mais importantes. 
Considerando-se o perfil dos entrevistados, obteve-se um resultado que caracteriza a hospitalidade na UPC/HUB em grau considerado bom. Gentileza, atenção e atendimento das equipes de saúde; acesso ao serviço. Porém, como falhas, foram citadas as instalações: espaços inadequados, quartos e banheiros desconfortáveis, móveis velhos e higienização precária.

Portanto, sugere-se a adequação dessas variáveis. Assim será possível criar um ambiente agradável para quem chega com a certeza de receber bom atendimento; imprescindível na hospitalidade em qualquer área, pois, reduz o estresse e estabelece um nível de confiança e satisfação, além de minimizar a imagem negativa sobre o ambiente hospitalar e possibilitar um clima agradável, onde a hospitalidade esteja presente em toda e qualquer ação dispensada ao cliente de saúde. Mediante estes resultados espera-se que o Instituto da Criança (em construção, Anexo D), com espaços e acomodações planejadas possa receber a criança, adolescente e acompanhante e, assim, superar as deficiências supracitadas. 


\section{REFERÊNCIAS}

BAUER, M. W.; GASKEL, G. Pesquisa Qualitativa Contexto, I magem e Som. 3. ed. Petrópolis: Vozes, 2004.

BECKER, H.S. M étodos de pesquisa em Ciências Sociais. 4. ed. São Paulo: Hucitec, 1999, p. 117.

BOEGER, M. A. G estão em H otelaria H ospitalar. 2. ed. São Paulo: Atlas, 2005.

BRASIL. IBGE. Disponível em: <http://www..ibge.gov./ibgeteen/pesquisas/família.html>. Acesso em: 08 set. 2009.

Ministério da Saúde. Secretaria de Atenção à Saúde. Núcleo Técnico de Política

Nacional de Humanização. A mbiência. Brasília, DF: 2008.

Ministério da Saúde. Secretaria de Assistência à Saúde. Programa Nacional de Humanização da Assistência Hospitalar. Brasília, DF: 2001.

Ministério da Saúde. Secretaria de Assistência á Saúde. CNS. Diretrizes e Normas Regulamentadoras de Pesquisas envolvendo seres humanos. Brasília, DF: 1997.

CAMARGO, L. O. L. Hospitalidade. São Paulo: Aleph, 2005.

CAMPOS, J. R. V. Introdução ao Universo da H ospitalidade. Campinas, SP: Prós, 2005.

CARDOSO, A. J. C. C. et al. A crise dos hospitais de ensino brasileiros: o caso do Hospital Universitário de Brasília. Mimeo.

CRISTO, R. C. A I nser ção do A companhante em Unidades de Internação Pediátrica no Distrito Federal. 1999. Dissertação (Mestrado em Enfermagem em Saúde Pública) Departamento de Enfermagem Materno-Infantil e Saúde Pública, Escola de Enfermagem de Ribeirão Preto, São Paulo, 1999.

DENCKER, A.F. M. A Abordagem Científica em Hospitalidade. In: DENCKER, A. F. M. (Org.). H ospitalidades: Cenários e Oportunidades. São Paulo: Pioneira Thomson Learning, 2003.

DYTZ, J. L. G. M odo de Vida da M ãe ea Saúde Infantil. 1998. Tese (Doutorado em Enfermagem) - Programa Interunidades de Doutoramento das Escolas de Enfermagem de Ribeirão Preto, São Paulo, 1998.

GENEHR, V. T. A H ospitalidade no A mbiente H ospitalar. 2008. Projeto de Pesquisa (Bacharelado em Turismo) - Universidade de Caxias do Sul, Rio Grande do Sul, 2008.

GRINOVER, L. Hospitalidade: Um Tema a ser Reestudado. In: DIAS, C. M. M. (Org.). Hospitalidade: Reflexões e Perspectivas. Barueri: Manole; 2002.

LÜDKE, M.; MARLI, A. E. D. A. Pesquisa em Educação: Abordagens qualitativas. São Paulo: E. P. U, 1986.

MARCONI, M. A.; LAKATOS, E. M. Técnicas de pesquisa: planejamento e execução de pesquisas, amostragens e técnicas de pesquisa, elaboração, análise e interpretação de dados. 5 . ed. São Paulo: Atlas, 2002.

MINAYO, M. C. de S. (Org.). O desafio do conhecimento: pesquisa qualitativa em saúde. 11. ed. São Paulo: Hucitec, 2008. 
PEREZ, D. O. Os Significados dos Conceitos de Hospitalidade em KANT e a Problemática do Estrangeiro. K ONVER GE NCI AS Filosofia y Culturas em Diálogo. Ano IV, n. 15, 2007.

QUEVEDO, M. F. Hospitalidade: Um Estudo de Caso do Hospital Unimed Nordeste RS. Dissertação (Mestrado em Turismo) - Universidade de Caxias do Sul, Rio Grande do Sul, 2006.

TEICHMANN, I. M. Cardápio - Técnicas e Criatividades. 5. ed. Caxias do Sul: EDUCS, 2000.

WATANABE, S. Hospitalidade: Uma abordagem para Melhoria da Qualidade. Disponível em: <http://hospitalar.com/Opiniões/Opiniões-1176.html>. Acesso em: 06 jul. 2008.

VERBISTE, C. F. A G estão da Hospitalidade sob a Perspectiva da Humanização dos Hospitais. 2006. 
APÊNDICES 


\section{APÊNDICE I}

Universidade de Brasília

Centro de Excelência em Turismo

Curso de Especialização La to Senso- Hotelaria Hospitalar

Termo de Consentimento Livre e Esclarecido

$\mathrm{Eu}$ declaro que, após ter sido convidado e

convenientemente esclarecido (a) pela pesquisadora Tereza Garcia Braga, aluna do Curso de Especialização Lato Senso- Hotelaria Hospitalar da Universidade de Brasília, consinto em participar da Pesquisa intitulada “G estão se H ospitalidade na Unidade de Pediatria Clínica do Hospital Universitário de Brasília", sob orientação do Prof ${ }^{a}$. Drª . Iara Lúcia Gomes Brasileiro, e conceder uma entrevista e responder a um questionário que tem como objetivos: analisar a hospitalidade na Unidade de Pediatria Clínica do Hospital Universitário da Universidade de Brasília.

Sei que as informações são sigilosas, que não serei identificado (a) e que os resultados serão codificados e utilizados exclusivamente para esta pesquisa.

Sei que tenho liberdade para participar e para retirar o consentimento em qualquer momento.

Estou ciente de que, não receberei qualquer valor em dinheiro e os resultados gerais serão divulgados por meio de publicações cientificas e apresentados em eventos da mesma natureza.

Se eu tiver dúvidas ou perguntas relativas ao estudo ou aos meus direitos relativos a minha participação, posso contactar a Tereza Garcia Braga, no telefone (61) 9963-6008 ou e-mail terezagarciabraga@hotmail.com

Brasília, Maio/2009.

Assinatura do participante:

RG:

Assinatura da pesquisadora:

RG: 


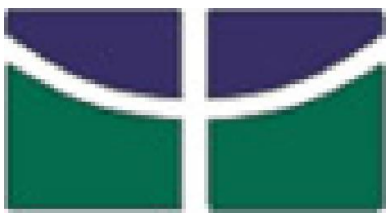

Univer sidade de Brasília - UnB

Centro de Excelência em Turismo

Curso de Especialização L ato Senso- Hotelaria Hospitalar

\section{Apêndice- 2}

Questionário de avaliação da Hospitalidade na Unidade de Pediatria do Hospital Univer sitário de Brasília

Este questionário será respondido pelos acompanhantes das crianças e adolescentes hospitalizados durante o período da pesquisa e que aceitarem participar da mesma.

Todos os dados coletados nesta pesquisa terão um tratamento estritamente confidencial e serão apresentados sempre de forma coletiva. Em nenhuma hipótese haverá identificação dos respondentes ou divulgação personalizada das informações fornecidas pelos acompanhantes.

Obrigada por sua prestimosa colaboração!

Pesquisadora responsável: Tereza Garcia Braga

Contatos: fone-(61) 32738706, email: terezagarciabraga@ hotmail.com 
Questionário de avaliação da Hospitalidade na Unidade de Pediatria do Hospital Univer sitário de Brasília

\section{Perfil do Respondente}

\section{Sexo:}

( ) Masculino

( ) Feminino

2. Idade:

( ) até 20 anos

( ) de 21 a 30 anos

( ) de 31 a 40 anos
( ) de 41 a 50 anos

( ) de 51 a 60 anos

( ) acima de 60 anos

3. Grau de Instrução:

( ) sem escolaridade

( ) Ensino fundamental Incompleto

( ) Ensino Fundamental Completo

( ) Ensino Médio Incompleto

( ) Ensino Médio Completo

( ) Ensino Superior Incompleto

( ) Ensino Superior Completo

4. Procedência:

5. Número de pessoas na família:

6. Número de pessoas que trabalham na família:

7. R enda familiar:

( ) Abaixo de 01 salário mínimo

( ) de 01 a 02 salários mínimos

( ) de 2 a 04 salários mínimos

( ) de 04 a 06 salário mínimos

( ) de 06 a 08 salários mínimos

( ) acima de 08 salários mínimos 
8. Quanto tempo tem de hospitalização a criança ou o adolescente?

9. Número de hospitalizações nesta Unidade?

I. Q ualidades dos Serviços e I nstalações.

1. A cesso (facilidade em ser atendido) e presteza no atendimento (rapidez para ser atendido):

Nas questões dos itens I, II, III, IV e V avalie cada alternativa assinalando: M uito Fraco (M F), Fraco ( F ), Regular ( R ), Bom ( B ), M uito Bom ( M B) e Não Tenho Como Avaliar (NA)

\begin{tabular}{|c|c|c|c|c|c|c|}
\hline & $\begin{array}{l}\text { MF } \\
\text { NA }\end{array}$ & $\mathrm{F}$ & & & B & MB \\
\hline a) Rapidez na hospitalização. & ( ) & ( ) & ( ) & ( ) & ( ) & ( ) \\
\hline b) Acesso dos acompanhantes. & ( ) & ( ) & ( ) & ( ) & ( ) & ( ) \\
\hline c) Acesso dos familiares nos horários de visitas. & ( ) & ( ) & ( ) & ( ) & ( ) & ( ) \\
\hline d) Troca de acompanhantes. & ( ) & ( ) & ( ) & ( ) & ( ) & ( ) \\
\hline $\begin{array}{l}\text { d) Atendimento } \mathrm{e} \text { orientação sobre } \\
\text { funcionamento da unidade }\end{array}$ & & ( ) & ( ) & ( ) & ( ) & ( \\
\hline
\end{tabular}

2. Instalações, equipamentos auxiliar es nos cuidados e tratamento dos hospitalizados da Unidade de Pediatria Clínica:

\begin{tabular}{|c|c|c|c|c|c|c|}
\hline & $\begin{array}{l}\text { MF } \\
\text { NA }\end{array}$ & 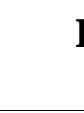 & & & B & MB \\
\hline a) Aparência da unidade pediátrica. & ( ) & ( ) & ( ) & $(\quad)$ & ( ) & ( ) \\
\hline b) Funcionamento dos equipamentos. & $($ ) & $($ ) & ( ) & $(\quad)$ & $(\quad)$ & ( ) \\
\hline $\begin{array}{l}\text { c)Conforto nas instalações físicas (área de } \\
\text { espera, quarto, banheiro, corredores). }\end{array}$ & $(\quad)$ & $($ ) & $($ ) & $(\quad)$ & $(\quad)$ & ( ) \\
\hline $\begin{array}{l}\text { d) Quantidade e qualidade das roupas de cama e } \\
\text { banho. }\end{array}$ & $($ ) & ( ) & ( ) & $($ ) & $(\quad)$ & ( ) \\
\hline e) Nível de silêncio & ( ) & ( ) & ( ) & $(\quad)$ & $(\quad)$ & ( ) \\
\hline $\begin{array}{l}\text { f)Qualidade das refeições oferecidas ao } \\
\text { acompanhante e paciente }\end{array}$ & $($ ) & ( ) & ( ) & $(\quad)$ & $(\quad)$ & ( ) \\
\hline g) Acesso ao telefone & $($ ) & $($ ) & $($ ) & $(\quad)$ & $(\quad)$ & $($ ) \\
\hline $\begin{array}{l}\text { h)Espaço para atividades (convivência, } \\
\text { comunicação, artes, relaxamento, leitura, TV, } \\
\text { atividades recreativas entre outros). }\end{array}$ & $($ ) & ( ) & ( ) & $(\quad)$ & ( & ( ) \\
\hline $\begin{array}{l}\text { j)Mobiliário (cadeiras, cama, berço, armários } \\
\text { entre outros) }\end{array}$ & $($ ) & $($ ) & ( ) & $($ ) & ) & ( ) \\
\hline
\end{tabular}


3. A tendimento prestado pela equipe médica e de enfermagem

\begin{tabular}{|c|c|c|c|c|c|c|}
\hline & $\mathrm{MF}$ & $\mathrm{F}$ & $\mathrm{R}$ & B & M B & NA \\
\hline $\begin{array}{l}\text { a)Formas de identificação clara das equipes } \\
\text { médica e de enfermagem ( apresentação) }\end{array}$ & $($ ) & ( ) & ( ) & $(\quad)$ & $(\quad)$ & $(\quad)$ \\
\hline b)Gentileza. & () & $(\quad)$ & $($ ) & $(\quad)$ & $(\quad)$ & $($ ) \\
\hline c)Interesse e atenção ao caso. & $($ ) & $(\quad)$ & $($ ) & $(\quad)$ & $(\quad)$ & $($ ) \\
\hline d)Compreensão das necessidades & ( ) & $(\quad)$ & ( ) & $(\quad)$ & $(\quad)$ & ( ) \\
\hline e)Privacidade no atendimento. & () & $(\quad)$ & () & $(\quad)$ & $(\quad)$ & $($ ) \\
\hline $\begin{array}{l}\text { f)Informações claras e compreensíveis sobre } \\
\text { o diagnostico e tratamento }\end{array}$ & $($ ) & ( ) & ( ) & ( ) & $(\quad)$ & ( ) \\
\hline
\end{tabular}

4. A tendimento prestado pela equipe de Pedagogia e R ecreação:

\begin{tabular}{|c|c|c|c|c|c|c|}
\hline & MF & $\mathrm{F}$ & $\mathrm{R}$ & B & MB & NA \\
\hline $\begin{array}{l}\text { a) Formas de identificação clara da equipe de } \\
\text { pedagogia ( Apresentação/crachás) }\end{array}$ & () & $($ ) & ( ) & ( ) & $(\quad)$ & ( ) \\
\hline b) Gentileza. & ( ) & ( ) & ( ) & $($ ) & $(\quad)$ & ( ) \\
\hline c) Interesse e atenção ao caso. & $($ ) & $($ ) & $($ ) & $($ ) & $(\quad)$ & () \\
\hline d) Compreensão das necessidades. & ( ) & ( ) & ( ) & $($ ) & ( ) & ( ) \\
\hline e) Privacidade no atendimento. & $($ ) & $($ ) & $($ ) & $($ ) & $(\quad)$ & $($ ) \\
\hline $\begin{array}{l}\text { f) Informações claras e compreensíveis sobre } \\
\text { atividade lúdica, brinquedoteca na } \\
\text { recuperação da criança.. }\end{array}$ & ( ) & ( ) & ( ) & ( ) & $(\quad)$ & ( ) \\
\hline $\begin{array}{l}\text { g) Atividades pedagógicas oferecidas aos } \\
\text { hospitalizados }\end{array}$ & ( ) & ( ) & ( ) & $($ ) & $(\quad)$ & ( ) \\
\hline $\begin{array}{l}\text { h) Informações sobre atividades oferecidas } \\
\text { aos acompanhantes }\end{array}$ & ( ) & ( ) & ( ) & $($ ) & () & ( ) \\
\hline
\end{tabular}

5. A tendimento prestado pela equipe de Nutrição

$\begin{array}{llllll}M F & F & R & B & M B & N A\end{array}$

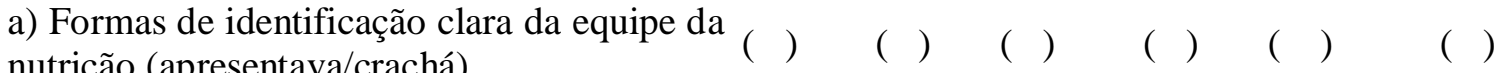
nutrição (apresentava/crachá).

\begin{tabular}{|c|c|c|c|c|c|c|}
\hline b) Gentileza. & $($ ) & $($ ) & $($ ) & $($ ) & $(\quad)$ & ( ) \\
\hline c) Interesse e atenção ao caso. & $($ ) & $($ ) & $($ ) & $($ ) & $(\quad)$ & $($ ) \\
\hline d) Compreensão das necessidades. & $($ ) & ( ) & $($ ) & ( ) & $($ ) & $($ ) \\
\hline e) Privacidade ao atendimento. & $($ ) & $($ ) & $($ ) & $($ ) & $(\quad)$ & $($ ) \\
\hline
\end{tabular}

g) Respeito e compreensão sobre os ( ) ( ) ( ) ( ) ( ) ( ) costumes e culturas alimentares.

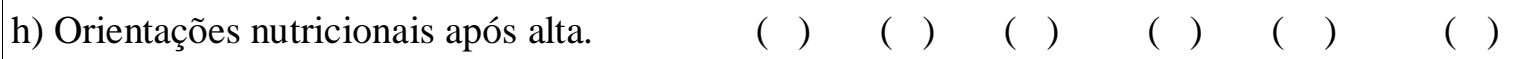




\section{I tens M ais Importantes.}

Selecione 2 itens que julgar mais importantes de cada grupo das questões abaixo

1. A cesso (facilidade de ser atendido) e presteza dos serviços (rapidez ser atendido):

a)( ) Facilidade de vaga para a internação.

b)( ) Facilidade e rapidez realização de exames.

c)( ) Facilidade e rapidez na entrega dos resultados de exames.

d)( ) Facilidade em receber informações sobre os exames realizados.

2. Clar eza das infor mações ofer ecidas aos acompanhantes:

a)( ) Identificação clara dos profissionais (apresentação/crachá dos profissionais);

b)( ) Informações claras e compreensíveis dadas sobre diagnóstico e tratamento do hospitalizado;

c)( ) Orientações sobre a continuação tratamento pós alta e;

d)( ) Informações e orientações claras sobre a prevenção de doenças e outros assuntos educativos para saúde.

\section{Qualidade da relação com os profissionais:}

a)( ) Gentileza;

b)( ) Interesse e atenção ao caso;

c)( ) Compreensão das suas necessidades;

d)( ) Atendimento realizado com privacidade e;

e)( ) Informações claras e compreensíveis sobre o diagnóstico e tratamento.

\section{Qualidade dos equipamentos/aparelhos e alimentação oferecidos pela} unidade pediátrica:

a)( ) Equipamentos funcionando e adequadamente;

b)( ) Roupas de cama e banho com boa quantidade e qualidade;

c)( ) Refeições que atendam com qualidade e;

d)( ) Telefone disponível para comunicação.

\section{Qualidade das instalações da unidade pediátrica:}

a)( )Higienização de quartos e banheiros adequados;

b)( ) Sinalização bem localizada e fácil de ser entendida;

c)( ) Quartos e banheiros confortáveis;

d)( ) Nível de silêncio adequado;

e)( ) Espaço para atividades de (convivência, comunicação trabalhos com artes, relaxamento, leitura, $\mathrm{TV}$, atividades recreativas entre outros). 
6. Qualidade do atendimento ao acompanhante dentro da unidade pediátrica:

a) ( ) Número de acompanhante por cliente;

b) ( ) Facilidade para o acesso familiares no horário de visitas;

c) ( ) Refeição para o acompanhante;

d) ( ) Mobiliário confortável: cama, cadeiras, banheiro armários entre outros).

IV. Infor mações Complementares.

1. O horário de visitas atende as necessidades da pessoa hospitalizada e dos familiares e amigos?

2. O Sr./Sra gostaria de fazer algum outro comentário sobre a maneira como foi atendido(a) nesta unidade pediátrica?

3. O Sr. /Sra. gostaria de fazer algum outro comentário sobre o funcionamento da unidade de pediatria clínica? 
ANEXOS 


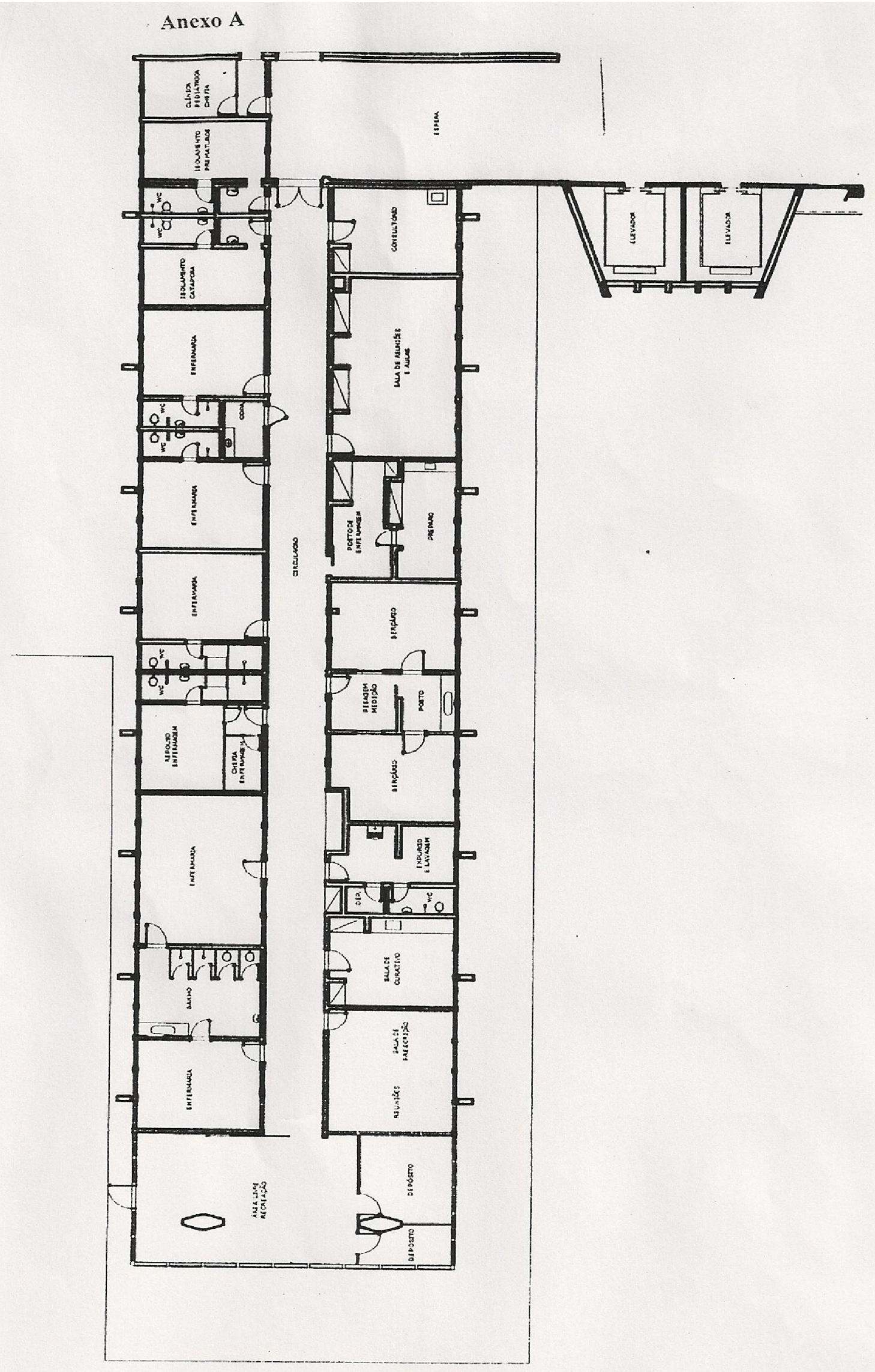




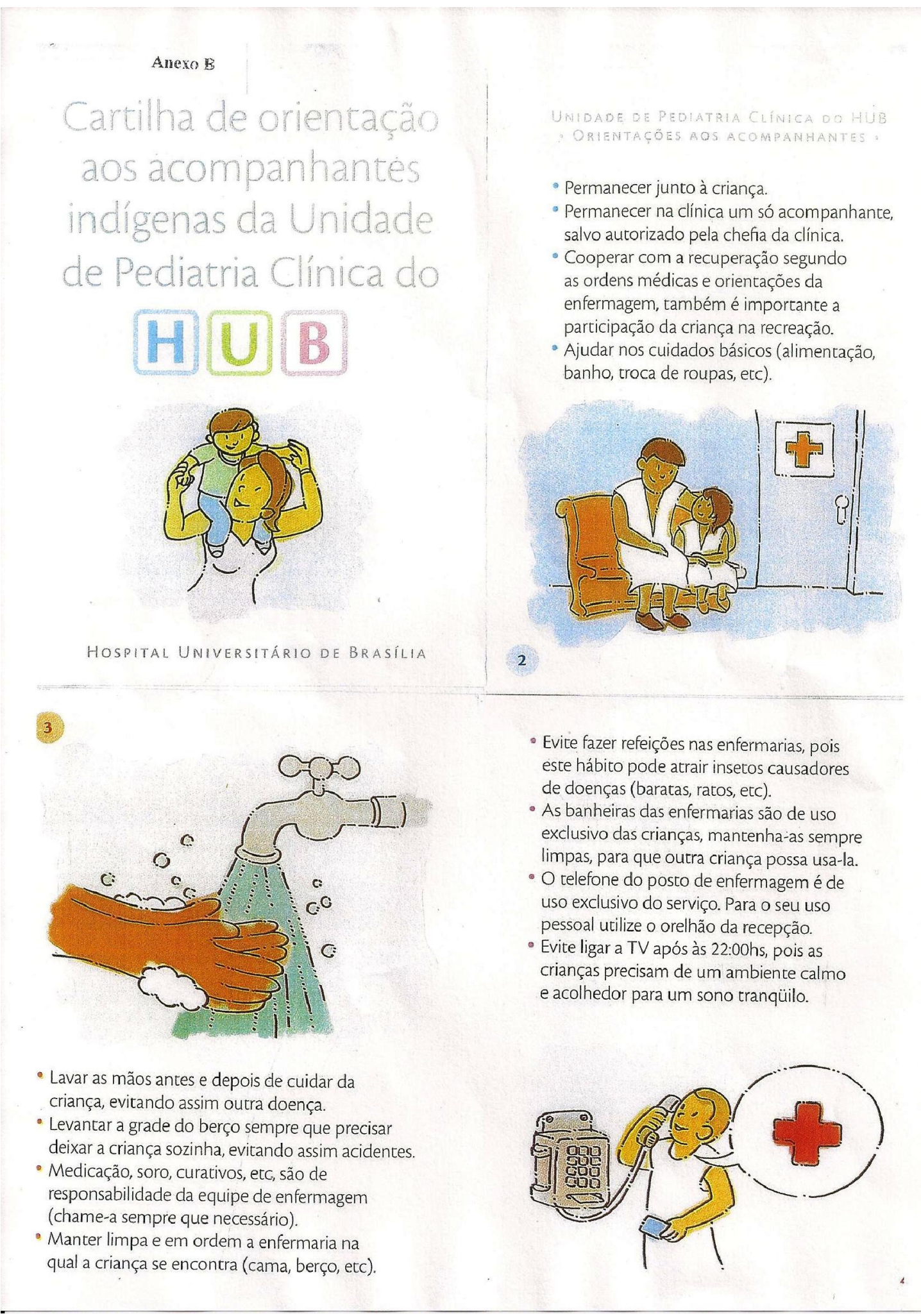


- Às 10:00hs as crianças que tiverem condições descerão em companhia do acompanhante para o banho de sol.

- Todos os acompanhantes deverão fazer uso da bata da clínica, evitando-se com isso a lavagem de roupas nas pias das enfermarias e disseminar infecções. Ajudando também, na identificação do mesmo dentro do hospital.

- Ao se ausentar da enfermaria

comunique à enfermagem.

- Deitar na cama/berço da criança, pode causar danos, pois o berço não suporta peso de um adulto, use a cadeira que se encontra ao lado do leito.

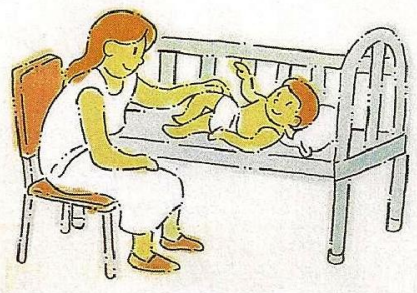

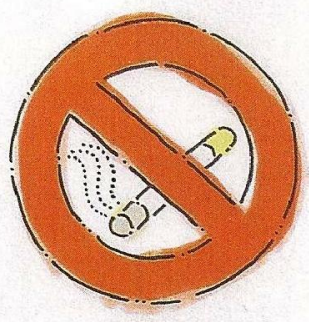

- Deixar visitantes sentar no leito da criança, mesmo que seja da família, proporciona maior risco de infecção.

- Evite discussões com outro acompanhante e funcionários. Procure sempre o diálogo, respeitando o problema de cada um.

- Não fume nas enfermarias, corredor e refeitório. O fumo prejudica você e quem encontra-se ao seu ladc - Os familiares têm direito à visitas nos horários préestabelecidos de três a quatro horas diariamente.

- Colabore com a enfermagem para que as crianças sejam pesadas diariamente às 7:30 da manhã.

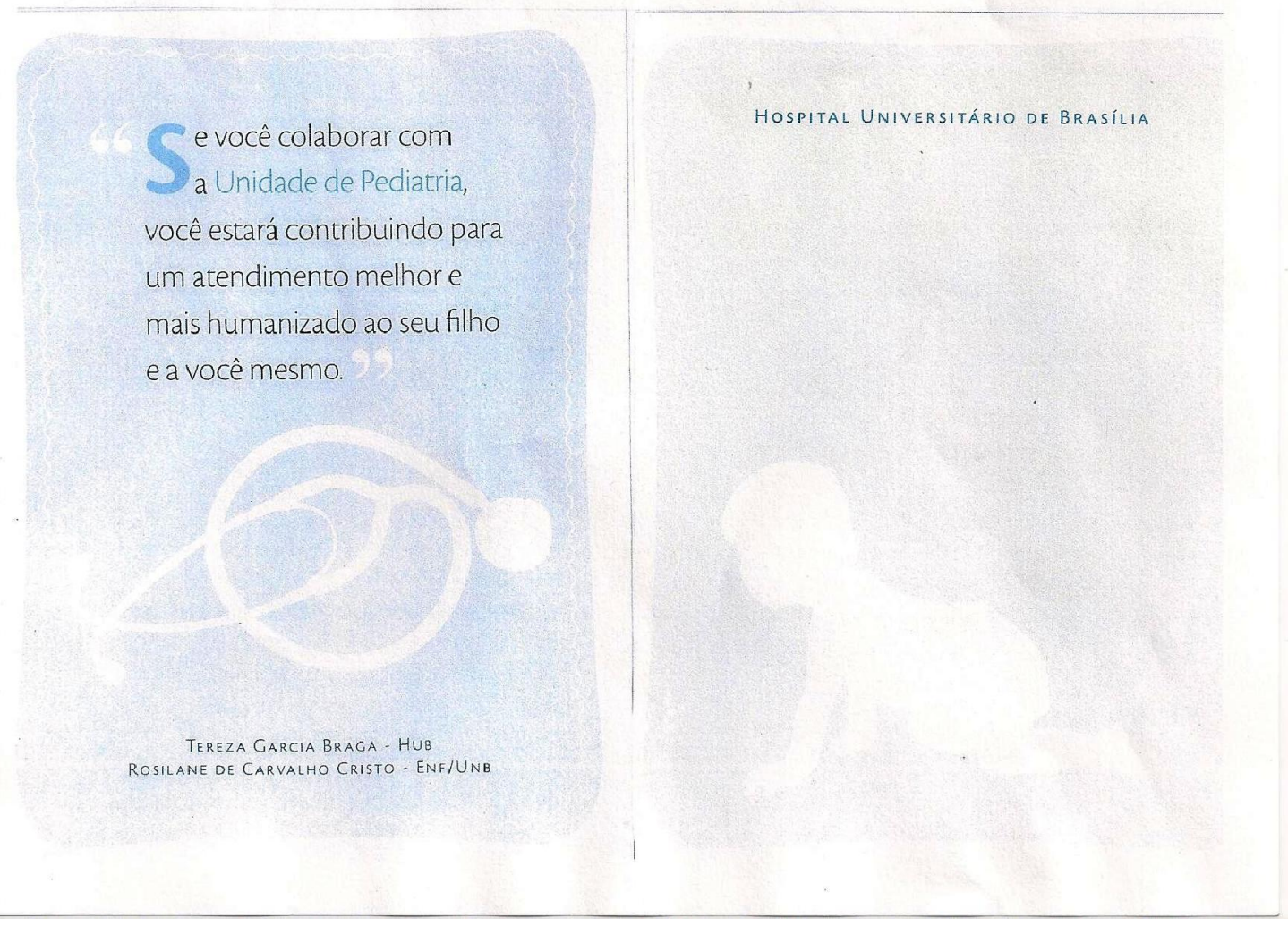




\section{ANÁlISE DE PROJETO DE PESQUISA}

\section{Registro de Projeto: CEP-FM 045/2009.}

Título: "Gestão de hospitalidade na unidade de pediatria clínica do Hospital Universitário de Brasília."

Pesquisador Responsável: Iara Lucia Gomes Brasileiro.

Documentos analisados: Folha de rosto, carta de encaminhamento, declaração de responsabilidade, protocolo de pesquisa, termo de consentimento livre e esclarecido, cronograma, bibliografia pertinente e currículo (s) de pesquisador (es).

Data de entrega: 20/05/2009.

Proposição do (a) relator (a)

( X ) Aprovação

( ) Não aprovação.

Data da primeira análise pelo CEP-FM/UNB: 26/05/2009

Data do parecer final do projeto pelo CEP-FM/UNB: 07/07/2009.

\section{PARECER}

Com base na Resolução CNS/MS no 196/96 e resoluções posteriores, que regulamentam a matéria, o Comitê de Ética em Pesquisa da Faculdade de Medicina da Universidade de Brasília decidiu APROVAR conforme parecer do (a) relator (a), o projeto de pesquisa acima especificado, quanto aos seus aspectos éticos.

1. Modificações no protocolo devem ser submetidas ao CEP, assim como a notificação imediata de eventos adversos graves;

2. $\mathrm{O}(\mathrm{s})$ pesquisador (es) deve $(\mathrm{m})$ apresentar relatórios periódicos do andamento da pesquisa ao CEP-FM.

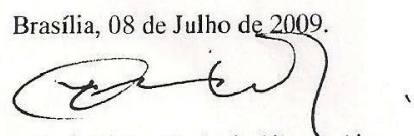

Prof. Elaine Mariu de Oliverma Alves Coordeadora do Comitể de Ética em Pesquisa Faculdade de Medicina-UnB 


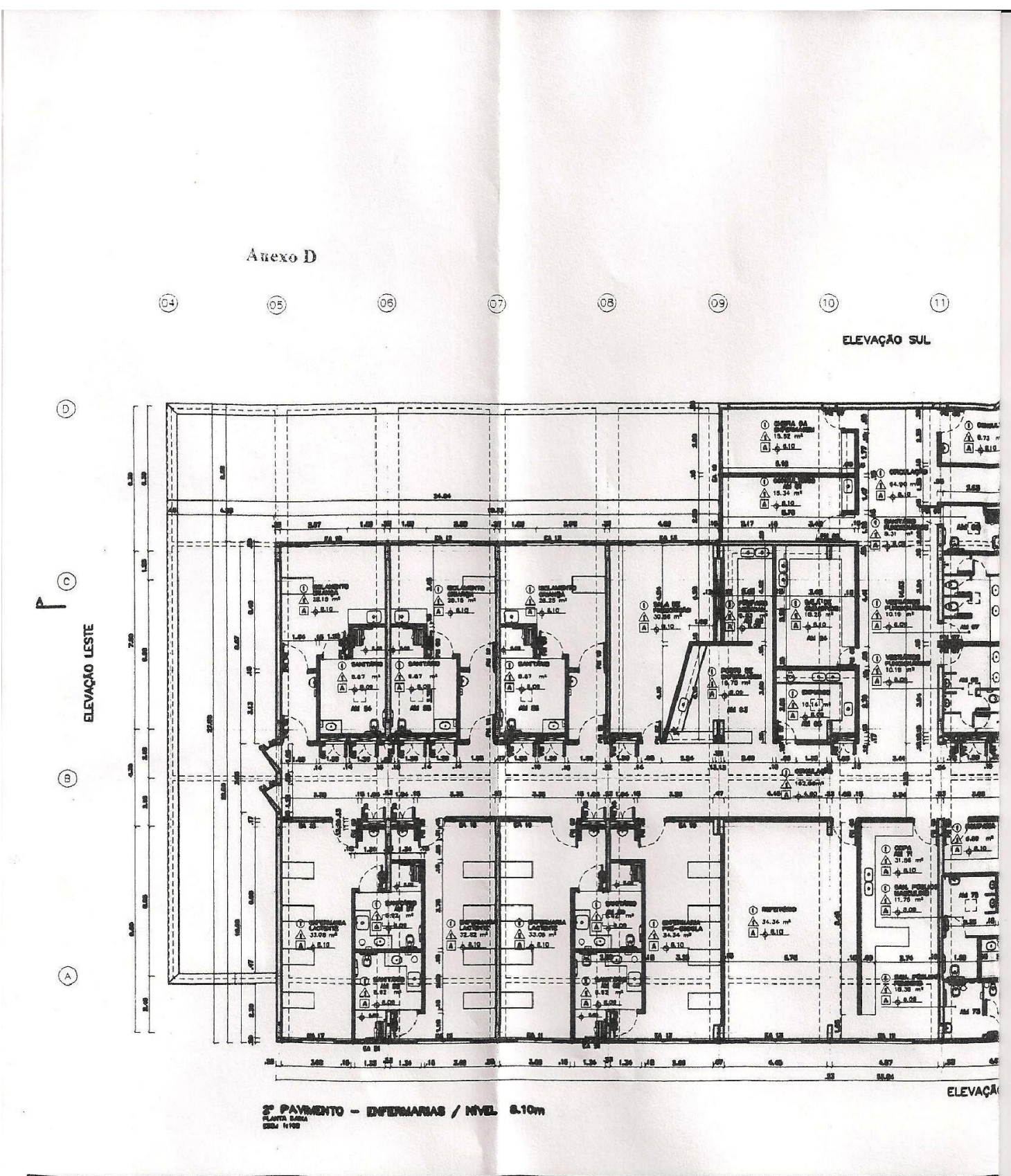



(12)
(14)
9 (15)
(15)
(1)
(18)
(19)
(20)

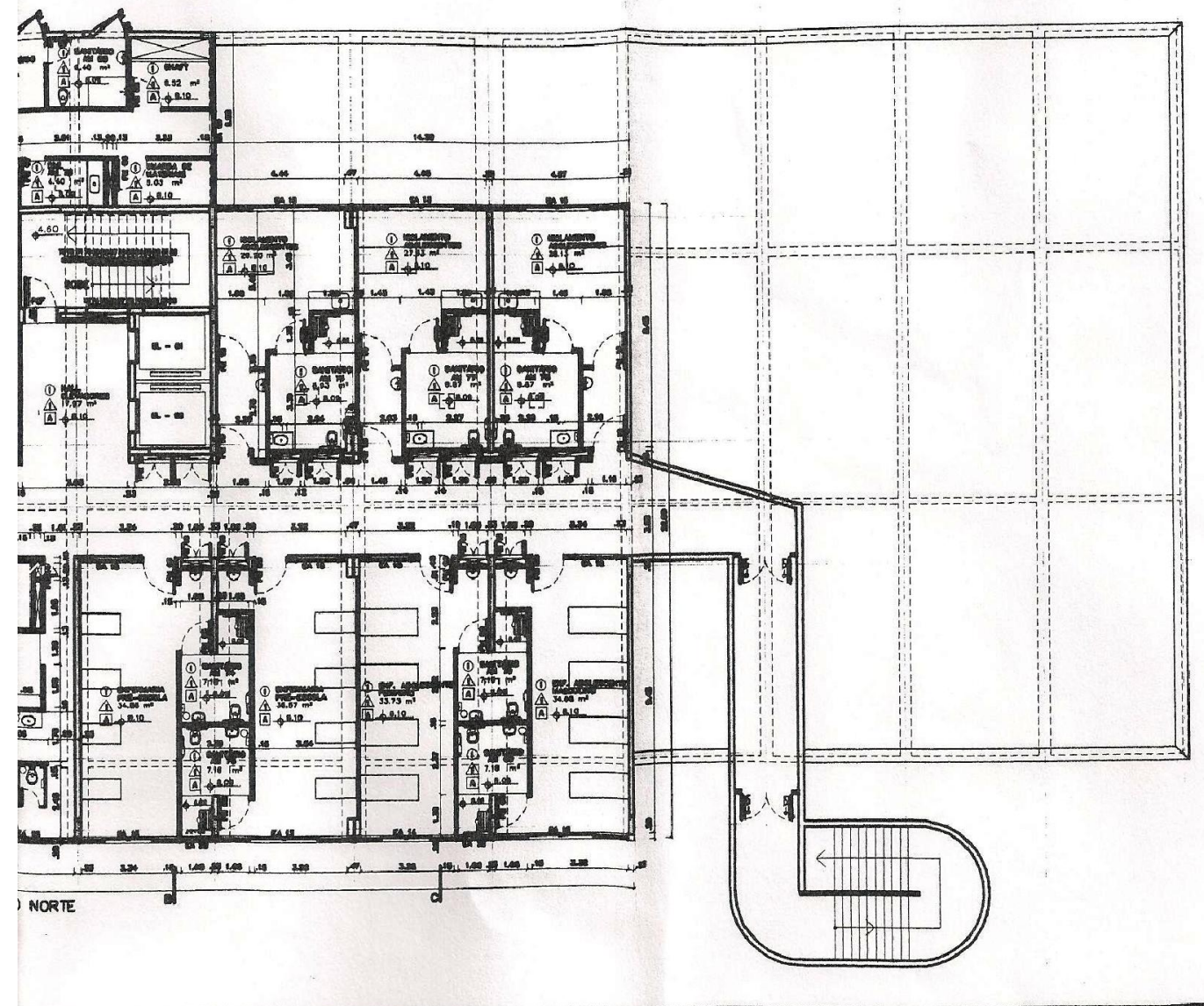

